\title{
Precise synthesis of linear polysiloxanes end-functionalized with alkynylsilyl groups by organocatalytic ring-opening polymerization of cyclotrisiloxanes
}

Keita Fuchise, * Kazuhiko Sato, Masayasu Igarashi*

Interdisciplinary Research Center for Catalytic Chemistry (IRC3), National Institute of Advanced Industrial Science and Technology (AIST), Central 5, 1-1-1 Higashi, Tsukuba, Ibaraki 305-8565, Japan

E-mail: k-fuchise@aist.go.jp (K.F.), masayasu-igarashi@aist.go.jp (M.I.)

\section{Supporting Information (SI)}

\section{Contents:}

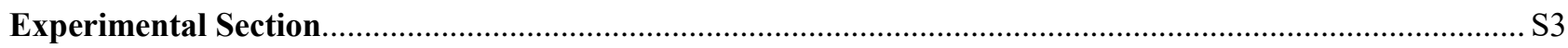

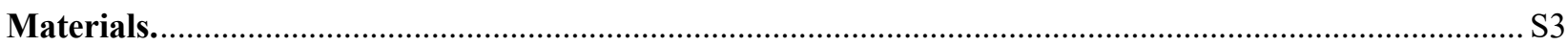

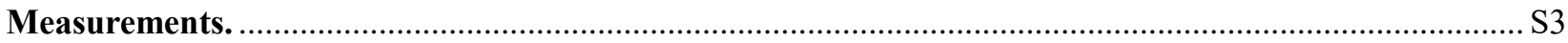

NMR

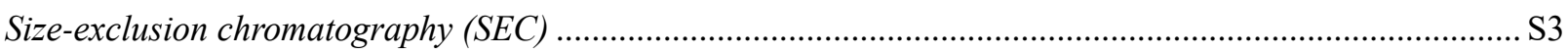

Matrix-assisted laser desorption ionization time-of-flight mass spectrometry (MALDI-TOF MS) ................. S4

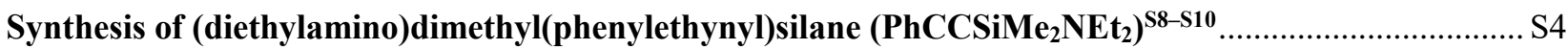

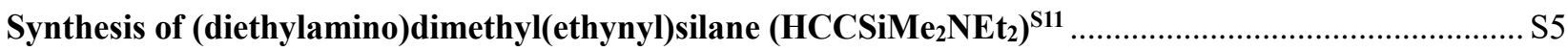

Synthesis of $\alpha, \omega$-bis[dimethyl(phenylethynyl)silyl]-terminated poly(dimethylsiloxane) (PDMS-(CCPh) $)^{\mathrm{S} 4}$

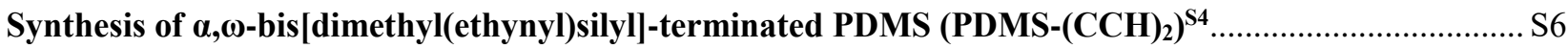

Synthesis of $\boldsymbol{\alpha}$-trimethylsilyl- $\omega$-ethynyldimethylsilyl-terminated PDMS (PDMS-CCH) ${ }^{\mathrm{S12}} \ldots \ldots \ldots \ldots \ldots \ldots \ldots . . . . . . . . . . . . .66$

Synthesis of $\alpha, \omega$-bis[ethynyldimethylsilyl]-terminated poly(dimethylsiloxane-co-allyl- (methyl)siloxane) (P(DMS-co-AMS)-(CCH) $)^{\mathrm{S} 1}$

Synthesis of $\quad \alpha, \omega$-bis[ethynyldimethylsilyl]-terminated poly(dimethylsiloxane-co-(3-cyanopropyl)methylsiloxane) (P(DMS-co-CNPMS)-(CCH) $)^{\mathrm{S2}}$ S7 Attempt of the synthesis of alkynyl-terminated PDMS by the conventional anionic ROP of D3 initiated by $\mathrm{Me}_{3} \mathrm{SiOLi}$. S8

Huisgen reaction for alkynylsilyl-terminated polysiloxanes (Table 2) S9

Determination of number-average degree of polymerization $\left(<X_{\mathrm{n}}>\right)$ and $M_{\mathrm{n}, \mathrm{NMR}}$ of the polysiloxane using ${ }^{1}$ H NMR spectroscopy.

NMR spectra, molar mass distributions, MALDI-TOF MS spectra of the products ................................. S12

Figure S1. Positive-ion MALDI-TOF MS spectra of PDMS end-functionalized with bis[(phenylethynyl)dimethylsilyl] groups (PDMS- $(\mathrm{CCPh})_{2}, M_{\mathrm{n}, \mathrm{NMR}}=6.02 \mathrm{kDa}$ and $\bigoplus_{\mathrm{M}}=1.08_{0}$ ) (Table 1 entry 1$)$.

Figure S2. Positive-ion MALDI-TOF MS spectra of PDMS end-functionalized with bis[(ethynyl)dimethylsilyl] groups (PDMS- $(\mathrm{CCH})_{2}, M_{\mathrm{n}, \mathrm{NMR}}=6.01 \mathrm{kDa}$ and $\bigoplus_{\mathrm{M}}=1.09_{9}$ ) (Table 1, entry 2). 
Figure S3. ${ }^{1} \mathrm{H}$ NMR and ${ }^{29} \mathrm{Si}\left\{{ }^{1} \mathrm{H}\right\}$ NMR spectra, molar-mass distribution, and positive-ion MALDI-TOF MS spectra of poly[dimethylsiloxane-co-allyl(methyl)siloxane] end-functionalized with dimethyl(ethynyl)silyl groups (P(DMS-co-AMS)-(CCH) $)_{2}, M_{\mathrm{n}, \mathrm{NMR}}=6.25 \mathrm{kDa},\left\langle X_{\mathrm{n}, \mathrm{D}} / X_{\mathrm{n}, \mathrm{A}}\right\rangle=49.4 / 24.0$, and $\emptyset_{\mathrm{M}}=1.14_{8}$ ) (Table 1, entry 5).

Figure S4. ${ }^{1} \mathrm{H}$ NMR and ${ }^{29} \mathrm{Si}\left\{{ }^{1} \mathrm{H}\right\}$ NMR spectra, molar-mass distribution, and positive-ion MALDI-TOF MS spectra of poly[dimethylsiloxane-co-(3-cyanopropyl)methylsiloxane] end-functionalized with dimethyl(ethynyl)silyl groups (P(DMS-co-CNPMS)-(CCH) ${ }_{2}, M_{\mathrm{n}, \mathrm{NMR}}=6.42 \mathrm{kDa},\left\langle X_{\mathrm{n}, \mathrm{D}} / X_{\mathrm{n}, \mathrm{CNP}}\right\rangle=45.2 / 22.7$, and $\bigoplus_{\mathrm{M}}=1.069$ ) (Table 1, entry 6).

Figure S5. ${ }^{1} \mathrm{H}$ NMR and ${ }^{29} \mathrm{Si}\left\{{ }^{1} \mathrm{H}\right\}$ NMR spectra, molar-mass distribution, and positive-ion MALDI-TOF MS spectra of $\alpha$-trimethylsilyl- $\omega$-dimethyl(ethynyl)silyl-PDMS $\left(M_{\mathrm{n}, \mathrm{NMR}}=2.96 \mathrm{kDa},\left\langle X_{\mathrm{n}, \mathrm{D}}\right\rangle=38.2\right.$, and $\bigoplus_{\mathrm{M}}=$ 1.112) (Table 1, entry 4).

Figure S6. ${ }^{1} \mathrm{H}$ NMR spectrum of $\alpha$-trimethylsilyl- $\omega$-dimethyl(phenyl)silyl-PDMS obtained from the polymerization of D3 using $\mathrm{Me}_{3} \mathrm{SiOLi}$ as an initiator and $\mathrm{HCCSiMe}_{2} \mathrm{NEt}_{2}$ and $\mathrm{PhSiMe}_{2} \mathrm{Cl}$ as end-capping agents (Scheme 3, $M_{\mathrm{n}, \mathrm{NMR}}=8.29 \mathrm{kDa},\left\langle X_{n}>=108.7\right.$, and $\bigoplus_{\mathrm{M}}=1.08_{5}$ ).

Figure S7. ${ }^{1} \mathrm{H}$ NMR and ${ }^{29} \mathrm{Si}\left\{{ }^{1} \mathrm{H}\right\}$ NMR spectra, molar-mass distribution, and positive-ion MALDI-TOF MS spectra of the product $\left(M_{\mathrm{n}, \mathrm{SEC}}=3.80 \mathrm{kDa}, \emptyset_{\mathrm{M}}=1.08_{2}\right)$ of the reaction between PDMS- $(\mathrm{CCPh})_{2}\left(M_{\mathrm{n}, \mathrm{SEC}}=\right.$ $3.54 \mathrm{kDa}, \bigoplus_{\mathrm{M}}=1.08_{0}$ ) and $\mathrm{N}_{3} \mathrm{BnBr}$ under the non-catalytic condition (Table 2, entry 1).

Figure S8. ${ }^{1} \mathrm{H}$ NMR and ${ }^{29} \mathrm{Si}\left\{{ }^{1} \mathrm{H}\right\}$ NMR spectra, molar-mass distribution, and positive-ion MALDI-TOF MS spectra of the product $\left(M_{\mathrm{n}, \mathrm{SEC}}=2.91 \mathrm{kDa}, \bigoplus_{\mathrm{M}}=1.10_{1}\right)$ of the reaction between PDMS- $(\mathrm{CCH})_{2}\left(M_{\mathrm{n}, \mathrm{SEC}}=2.51\right.$ $\mathrm{kDa}, \bigoplus_{\mathrm{M}}=1.09_{9}$ ) and $\mathrm{N}_{3} \mathrm{BnBr}$ under the non-catalytic condition (Table 2, entry 2)...... S18

Figure S9. ${ }^{1} \mathrm{H}$ NMR and ${ }^{29} \mathrm{Si}\left\{{ }^{1} \mathrm{H}\right\}$ NMR spectra, molar-mass distribution, and positive-ion MALDI-TOF MS spectra of the product $\left(M_{\mathrm{n}, \mathrm{SEC}}=3.28 \mathrm{kDa}, \bigoplus_{\mathrm{M}}=1.13_{8}\right)$ of the reaction between P(DMS-co-CNPMS $)-(\mathrm{CCH})_{2}$ $\left(M_{\mathrm{n}, \mathrm{SEC}}=3.98 \mathrm{kDa}, M_{\mathrm{n}, \mathrm{NMR}}=6.42 \mathrm{kDa},\left\langle X_{\mathrm{n}, \mathrm{D}} / \mathrm{X}_{\mathrm{n}, \mathrm{CNP}}\right\rangle=45.2 / 22.7\right.$, and $\left.\emptyset_{\mathrm{M}}=1.069\right)$ and $\mathrm{N}_{3} \mathrm{BnBr}$ under the non-catalytic condition (Table 2, entry 5 )

Figure S10. ${ }^{1} \mathrm{H}$ NMR spectrum and molar-mass distribution of the product $\left(M_{\mathrm{n}, \mathrm{SEC}}=3.66 \mathrm{kDa}, \emptyset_{\mathrm{M}}=1.28_{6}\right)$ of the reaction between P(DMS-co-AMS)- $(\mathrm{CCH})_{2}\left(M_{\mathrm{n}, \mathrm{SEC}}=3.07 \mathrm{kDa}, M_{\mathrm{n}, \mathrm{NMR}}=6.25 \mathrm{kDa},\left\langle X_{\mathrm{n}, \mathrm{D}} / \mathrm{X}_{\mathrm{n}, \mathrm{A}}\right\rangle=\right.$ 49.4/24.0, and $\bigoplus_{\mathrm{M}}=1.148$ ) and $\mathrm{N}_{3} \mathrm{BnBr}$ under the non-catalytic condition (Table 2, entry 6)... S20

Figure S11. ${ }^{1} \mathrm{H}$ NMR and ${ }^{29} \mathrm{Si}\left\{{ }^{1} \mathrm{H}\right\}$ NMR spectra, molar-mass distribution, and positive-ion MALDI-TOF MS spectra of the product $\left(M_{\mathrm{n}, \mathrm{SEC}}=2.93 \mathrm{kDa}, \bigoplus_{\mathrm{M}}=1.08_{1}\right)$ of the reaction between PDMS- $(\mathrm{CCH})_{2}\left(M_{\mathrm{n}, \mathrm{SEC}}=\right.$ $\left.2.51 \mathrm{kDa}, \bigoplus_{\mathrm{M}}=1.109_{9}\right)$ and $\mathrm{N}_{3} \mathrm{BnBr}$ catalyzed by the catalyst $\mathrm{A}\left(\mathrm{CuBr}+\mathrm{Et}_{3} \mathrm{~N}\right.$, Table 2, entry 7).

Figure S12. ${ }^{1} \mathrm{H}$ NMR and ${ }^{29} \mathrm{Si}\left\{{ }^{1} \mathrm{H}\right\}$ NMR spectra, molar-mass distribution, and positive-ion MALDI-TOF MS spectra of the product $\left(M_{\mathrm{n}, \mathrm{SEC}}=2.78 \mathrm{kDa}, \emptyset_{\mathrm{M}}=1.10_{9}\right)$ of the reaction between PDMS- $(\mathrm{CCH})_{2}\left(M_{\mathrm{n}, \mathrm{SEC}}=\right.$ $\left.2.51 \mathrm{~kg} \mathrm{~mol}^{-1}, \bigoplus_{\mathrm{M}}=1.09_{9}\right)$ and $\mathrm{N}_{3} \mathrm{HexOH}$ catalyzed by the catalyst $\mathrm{A}\left(\mathrm{CuBr}+\mathrm{Et}_{3} \mathrm{~N}\right.$, Table 2, entry 9). For the SEC, the hydroxy groups in the product were treated with chlorodimethyl(vinyl)silane and pyridine to obtain the elution curve comparable with the starting PDMS- $(\mathrm{CCH})_{2}$. S22

Figure S13. ${ }^{1} \mathrm{H}$ NMR and ${ }^{29} \mathrm{Si}\left\{{ }^{1} \mathrm{H}\right\}$ NMR spectra, molar-mass distribution, and positive-ion MALDI-TOF MS spectra of the product $\left(M_{\mathrm{n}, \mathrm{SEC}}=3.31 \mathrm{kDa},{D_{\mathrm{M}}}=1.12_{7}\right)$ of the reaction between $\mathrm{P}(\mathrm{DMS}-\mathrm{co}-\mathrm{AMS})-(\mathrm{CCH})_{2}\left(M_{\mathrm{n}, \mathrm{SEC}}=3.07 \mathrm{kDa}, \oplus_{\mathrm{M}}=1.14_{8}\right)$ and $\mathrm{N}_{3} \mathrm{BnBr}$ catalyzed by the catalyst $\mathrm{A}(\mathrm{CuBr}+$ $\mathrm{Et}_{3} \mathrm{~N}$, Table 2, entry 11). S23 


\section{Experimental Section}

\section{Materials.}

Hexamethylcyclotrisiloxane (D3, Tokyo Kasei Kogyo (TCI), 98\%), diethylamine (Sigma-Aldrich, >99.0\%), and triethylamine $\left(\mathrm{Et}_{3} \mathrm{~N}\right.$, FUJIFILM Wako, $\left.>98 \%\right)$ were purified by distillation in the presence of calcium hydride $\left(\mathrm{CaH}_{2}\right)$ under reduced pressure and a nitrogen atmosphere prior to use. $N, N, N^{\prime}, N^{\prime \prime}, N^{\prime \prime}$-pentamethyldiethylenetriamine (PMDETA, TCI, >99.0\%) was dried over activated molecular sieves $4 \AA$ prior to use.

Sodium acetylide (Sigma-Aldrich, suspension 18 wt. \% slurry in xylene: light mineral oil, 95\% (purity of contained acetylide)), lithium phenylacetylide (Sigma-Aldrich, $1.0 \mathrm{~mol} \mathrm{~L}^{-1}$ in THF), 4-bromobenzyl bromide (TCI, >98.0\%), 6-bromo-1-hexanol (FUJIFILM Wako, >96\%), sodium azide $\left(\mathrm{NaN}_{3}\right.$, FUJIFILM Wako, >98\%), copper(I) bromide (CuBr, FUJIFILM Wako, >99.9\%), pyridine (FUJIFILM Wako, dehydrated, >99.5\%), benzoic acid (Kanto, >99.5\%), trans-2-[3-(4-tert-butylphenyl)-2-methyl-2-propenylidene]malononitrile (DCTB, Aldrich, $\geq 98 \%$ ), silver trifluoroacetate (TFAAg, FUJIFILM Wako, $>97.0 \%$ ), sodium trifluoroacetate (TFANa, FUJIFILM Wako, >97.0\%), 'dry' diethyl ether ( $\mathrm{Et}_{2} \mathrm{O}$, FUJIFILM Wako, Super Dehydrated, $>99.5 \%$ ), acetonitrile $(\mathrm{MeCN}$, FUJIFILM Wako, $>99.5 \%)$, 'dry' dichloromethane $\left(\mathrm{CH}_{2} \mathrm{Cl}_{2}\right.$, FUJIFILM Wako, super dehydrated, water content $<$ $0.001 \%$ ), 'dry' toluene (Kanto, dehydrated -Super Plus-, water content $<0.001 \%$ ), and 'dry' tetrahydrofuran (THF, Kanto, dehydrated -Super Plus-, water content $<0.001 \%$ ), dry xylene (FUJIFILM Wako, deoxidized, $>80 \%(o-, m-, p$-xylene $))$ were used as received.

Allylpentamethylcyclotrisioxane $\quad(\mathrm{AD} 2),{ }^{\mathrm{S} 1} \quad$ (3-cyanopropyl)pentamethylcyclotrisiloxane $\quad$ (CNPD2), ${ }^{\mathrm{S} 2}$ 1-hydroxy-1,1,3,3,5,5,7,7,7-nonamethyltetrasiloxane $\quad(\mathrm{MeD} 4 \mathrm{OH}),{ }^{\mathrm{S} 3} \quad$ 1,3-trimethylene-2- $n$-propylguanidine (TMnPG), ${ }^{\mathrm{S} 4}$ 1,3-trimethylene-2-methylguanidine $\quad(\mathrm{TMMG}),{ }^{\mathrm{S} 1} \quad$ chloro(diethylamino)dimethylsilane $\left(\mathrm{ClSiMe}_{2} \mathrm{NEt}_{2}\right),{ }^{\mathrm{S} 5}$ 4-bromobenzyl azide $\left(\mathrm{N}_{3} \mathrm{BnBr}\right),{ }^{\mathrm{S} 6}$ and 6 -azido-1-hexanol $\left(\mathrm{N}_{3} \mathrm{HexOH}\right)^{\mathrm{S} 7}$ were synthesized as previously reported.

\section{Measurements.}

$N M R$

${ }^{1} \mathrm{H}(600 \mathrm{MHz}),{ }^{13} \mathrm{C}\left\{{ }^{1} \mathrm{H}\right\}(150 \mathrm{MHz})$, and ${ }^{29} \mathrm{Si}\left\{{ }^{1} \mathrm{H}\right\}$ (119 MHz) NMR spectra were recorded on a Bruker Biospin AVANCE III HD 600 NMR spectrometer with a CryoProbe. Chemical shifts were reported in $\delta(\mathrm{ppm})$ and were referenced to tetramethylsilane (TMS, $0.00 \mathrm{ppm}$ ) for ${ }^{1} \mathrm{H},{ }^{13} \mathrm{C}$, and ${ }^{29} \mathrm{Si}$.

\section{Size-exclusion chromatography (SEC)}

Size-exclusion chromatography (SEC) was performed at $45{ }^{\circ} \mathrm{C}$ using a Waters ACQUITY Advanced Polymer Chromatography (APC) System consisting of a p-Isocratic Solvent Manager (Model AIS), Sample Manager pFTN (Model ASM), Column Manager-S (Model AZC), PDA TS Detector (Model ADT), and Refractive Index (RI) Detector (Model URI) equipped with a Waters APC ${ }^{\mathrm{TM}}$ XT45 column (linear, $4.6 \mathrm{~mm} \times 150 \mathrm{~mm}$; pore size, $4.5 \mathrm{~nm}$; bead size, $1.7 \mu \mathrm{m}$; exclusion limit, 5000), a Waters APC ${ }^{\mathrm{TM}}$ XT200 column (linear, $4.6 \mathrm{~mm} \times 150 \mathrm{~mm}$; pore size, $20.0 \mathrm{~nm}$; bead size, $2.5 \mu \mathrm{m}$; exclusion limit, 70 000), and a Waters APC ${ }^{\mathrm{TM}}$ XT450 column (linear, 4.6 $\mathrm{mm} \times 150 \mathrm{~mm}$; pore size, $45.0 \mathrm{~nm}$; bead size, $2.5 \mu \mathrm{m}$; exclusion limit, 400000$)$ in toluene at a flow rate of 0.70 
$\mathrm{mL} \min ^{-1}$. The number-average molar mass $\left(M_{\mathrm{n}, \mathrm{SEC}}\right)$ and the molar-mass dispersity $\left(\nexists_{\mathrm{M}}\right)$ were determined based on a calibration curve prepared using polystyrene (PS) samples from a TSKgel ${ }^{\circledR}$ standard polystyrene oligomer kit (Tosoh) with weight-average molar mass $\left(M_{\mathrm{w}}\right)$ and $\left(\bigoplus_{\mathrm{M}}\right)$ values of $19.0 \times 10^{5} \mathrm{~g} \mathrm{~mol}^{-1}(1.04), 9.64 \times 10^{4} \mathrm{~g} \mathrm{~mol}^{-1}$ (1.01), $3.79 \times 10^{4} \mathrm{~g} \mathrm{~mol}^{-1}(1.01), 1.74 \times 10^{4} \mathrm{~g} \mathrm{~mol}^{-1}(1.01), 1.02 \times 10^{4} \mathrm{~g} \mathrm{~mol}^{-1}(1.02), 5.06 \times 10^{3} \mathrm{~g} \mathrm{~mol}^{-1}$ (1.02), $2.63 \times 10^{3} \mathrm{~g} \mathrm{~mol}^{-1}(1.05), 1.01 \times 10^{3} \mathrm{~g} \mathrm{~mol}^{-1}$ (1.16), and $5.9 \times 10^{2} \mathrm{~g} \mathrm{~mol}^{-1}$ (1.19), along with PS samples from Chemco Co. with $M_{\mathrm{w}}\left(\bigoplus_{\mathrm{M}}\right)$ values of $17.0 \times 10^{5} \mathrm{~g} \mathrm{~mol}^{-1}(<1.06), 4.75 \times 10^{4} \mathrm{~g} \mathrm{~mol}^{-1}(1.06), 9.00 \times 10^{3} \mathrm{~g} \mathrm{~mol}^{-1}(1.04)$, and $4.00 \times 10^{3} \mathrm{~g} \mathrm{~mol}^{-1}(1.03)$.

\section{Matrix-assisted laser desorption ionization time-of-flight mass spectrometry (MALDI-TOF MS)}

MALDI-TOF MS of the obtained polymers was performed using a Bruker autoflex ${ }^{\mathrm{TM}}$ speed TOF/TOF system with a Smartbeam laser (Bruker Daltonics). Spectra were acquired in the positive linear mode by accumulating 2500 to 5000 laser shots at a $19 \mathrm{kV}$ acceleration voltage. External calibration was performed using Tosoh TSKgel $^{\circledR}$ standard Polystyrene TS-502 $\left(M_{\mathrm{w}}=2.63 \mathrm{kDa}, \emptyset_{\mathrm{M}}=1.05\right)$ and TS-521 $\left(M_{\mathrm{w}}=5.06 \mathrm{kDa}, \emptyset_{\mathrm{M}}=1.02\right)$. In a typical measurement, a solution of the external standard was prepared by mixing TS-502 $\left(12.5 \mu \mathrm{L}, 10 \mathrm{mg} \mathrm{mL}^{-1}\right.$ in THF), TS-521 (12.5 $\mu \mathrm{L}, 10 \mathrm{mg} \mathrm{mL}^{-1}$ in THF), the matrix (DCTB, $50 \mathrm{mg} \mathrm{mL}^{-1}, 20 \mu \mathrm{L}$ ), and the cationization agent (TFAAg, $\left.2.2 \mathrm{mg} \mathrm{mL}^{-1}, 45 \mu \mathrm{L}\right)$. Solution of the samples were prepared by mixing polysiloxane $\left(30 \mathrm{mg} \mathrm{mL}^{-1}\right.$ in THF, $10 \mu \mathrm{L}$ ), the matrix (DCTB, $50 \mathrm{mg} \mathrm{mL}^{-1}, 20 \mu \mathrm{L}$ ), and the cationization agent (TFANa, $2.2 \mathrm{mg} \mathrm{mL}^{-1}, 45$ $\mu \mathrm{L})$. Approximately $10 \mu \mathrm{L}$ of the obtained mixture was spotted on a ground steel target plate and dried prior to measurements.

\section{Synthesis of (diethylamino)dimethyl(phenylethynyl)silane $\left(\mathrm{PhCCSiMe}_{2} \mathrm{NEt}_{2}\right)^{\mathrm{S8}-\mathrm{S} 10}$}

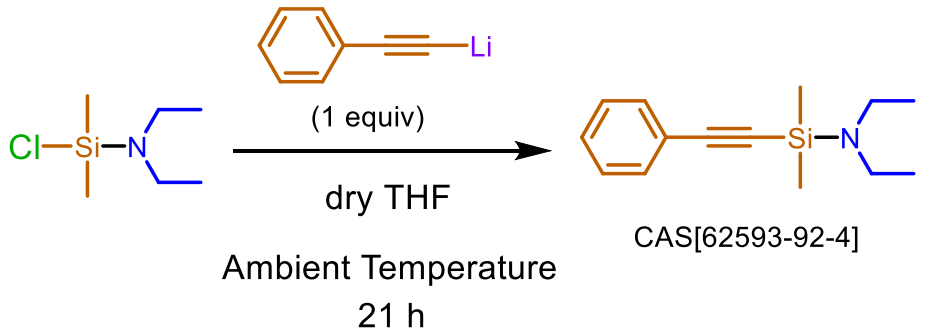

Lithium phenylacetylide (40.0 mL, $40.0 \mathrm{mmol}, 1.0 \mathrm{~mol} \mathrm{~L}^{-1}$ in THF) was added to a solution of chloro(diethylamino)dimethylsilane $(6.64 \mathrm{~g}, 40.0 \mathrm{mmol})$ at room temperature. After $21 \mathrm{~h}$, the solution was diluted with pentane $(40 \mathrm{~mL})$ and filtered through a glass filter. The filtrate was concentrated and distilled under reduced pressure to obtain $\mathrm{PhCCSiMe}_{2} \mathrm{NEt}_{2}$ as a colorless liquid. Yield: $5.04 \mathrm{~g}(21.8 \mathrm{mmol}, 54.5 \%)$.

B.p. $114-120{ }^{\circ} \mathrm{C} / 0.45 \mathrm{mmHg} .{ }^{1} \mathrm{H}$ NMR (600 MHz, $\left.\mathrm{CDCl}_{3}\right): \delta 7.49-7.40$ (m, 2H, o-aromatic), 7.32-7.25 (m, $3 \mathrm{H}, m$ - and $p$-aromatic), 2.90 (q, $\left.J=7.0 \mathrm{~Hz}, 4 \mathrm{H}, \mathrm{NCH}_{2}\right), 1.05$ (t, $\left.J=7.0 \mathrm{~Hz}, 6 \mathrm{H}, \mathrm{NCH}_{2} \mathrm{CH}_{3}\right), 0.28\left(\mathrm{~s}, 6 \mathrm{H}, \mathrm{SiCH}_{3}\right)$. ${ }^{13} \mathrm{C}\left\{{ }^{1} \mathrm{H}\right\}$ NMR (151 MHz, $\left.\mathrm{CDCl}_{3}\right): \delta 131.93$ (o-Ar), 128.33 (p-Ar), 128.16 (m-Ar), 123.38 (1-Ar), 103.82 (Ph-C), $94.20(\mathrm{Ph}-\mathrm{C} \equiv C), 40.23\left(\mathrm{NCH}_{2}\right), 15.58\left(\mathrm{NCH}_{2} \mathrm{CH}_{3}\right), 0.24\left(\mathrm{SiCH}_{3}\right) .{ }^{29} \mathrm{Si}\left\{{ }^{1} \mathrm{H}\right\} \mathrm{NMR}\left(119 \mathrm{MHz}, \mathrm{CDCl}_{3}\right): \delta-17.60$. 


\section{Synthesis of (diethylamino)dimethyl(ethynyl)silane (HCCSiMe2NEt $)^{\text {S11 }}$}

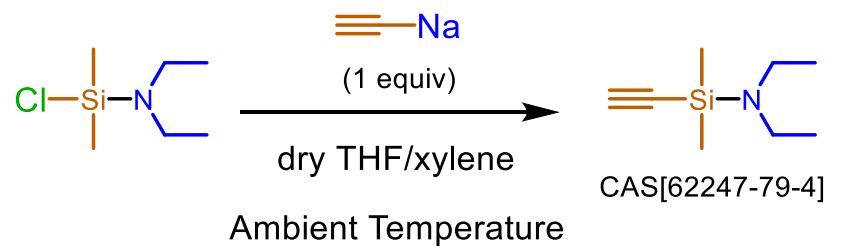

$22.5 \mathrm{~h}$

Sodium acetylide $(16.7 \mathrm{~g}, 62.6 \mathrm{mmol}, 18$ wt. \% slurry in xylene) was diluted with dry THF $(62.5 \mathrm{~mL})$ and added to a solution of chloro(diethylamino)dimethylsilane $(10.36 \mathrm{~g}, 62.51 \mathrm{mmol})$ in dry THF $(62.5 \mathrm{~mL})$ at room temperature. After $22.5 \mathrm{~h}$, the solution was centrifuged at $5000 \mathrm{rpm}$ for $1 \mathrm{~min}$. Then, the liquid phase was separated and further filtered through a syringe filter (PTFE, pore size $0.20 \mu \mathrm{L}$ ). The filtrate was concentrated and distilled under reduced pressure to obtain $\mathrm{HCCSiMe}_{2} \mathrm{NEt}_{2}$ as a colorless $37 \mathrm{wt} \%$ solution in xylene. Yield: $3.44 \mathrm{~g}$ (22.1 mmol, 35.4\%).

B.p. $127-134^{\circ} \mathrm{C}$ (as a mixture with xylene). ${ }^{1} \mathrm{H}$ NMR $\left(600 \mathrm{MHz}, \mathrm{CDCl}_{3}\right): \delta 2.85$ (q, $J=7.0 \mathrm{~Hz}, 4 \mathrm{H}, \mathrm{NCH}$ ), $2.33(\mathrm{~s}, 1 \mathrm{H}, \mathrm{C} \equiv \mathrm{CH}), 1.02\left(\mathrm{t}, J=7.0 \mathrm{~Hz}, 6 \mathrm{H}, \mathrm{NCH}_{2} \mathrm{CH}_{3}\right), 0.23(\mathrm{~s}, 6 \mathrm{H}, \mathrm{SiCH}) .{ }^{13} \mathrm{C}\left\{{ }^{1} \mathrm{H}\right\} \mathrm{NMR}\left(151 \mathrm{MHz}, \mathrm{CDCl}_{3}\right)$ : $\delta 91.59(\mathrm{HC} \equiv \mathrm{CSi}), 90.20(\mathrm{HC} \equiv C \mathrm{Si}), 40.12\left(\mathrm{NCH}_{2}\right), 15.50\left(\mathrm{NCH}_{2} \mathrm{CH}_{3}\right), 0.03\left(\mathrm{SiCH}_{3}\right) .{ }^{29} \mathrm{Si}\left\{{ }^{1} \mathrm{H}\right\} \mathrm{NMR}(119 \mathrm{MHz}$, $\left.\mathrm{CDCl}_{3}\right): \delta-17.71$.

\section{Synthesis of $\alpha, \omega$-bis[dimethyl(phenylethynyl)silyl]-terminated poly(dimethylsiloxane) (PDMS-(CCPh)2) $)^{\mathrm{S} 4}$}

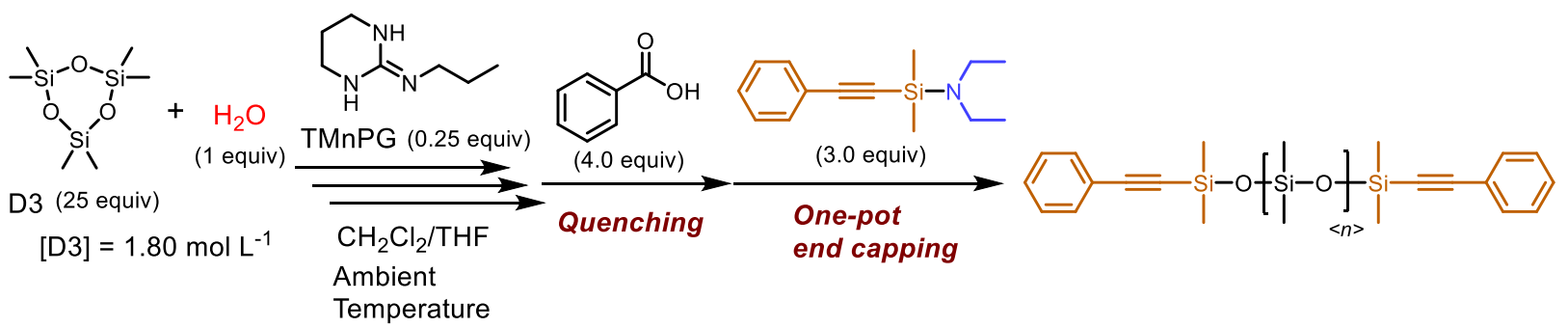

A toluene solution of TMnPG (100 mg mL $\mathrm{mL}^{-1}, 32.0 \mu \mathrm{L}, 22.6 \mu \mathrm{mol}, 0.25$ equiv) was added to a solution of D3 (504 mg, 2.27 mmol, 25 equiv) and a THF solution of $\mathrm{H}_{2} \mathrm{O}(1 / 99$ (v/v), $163 \mu \mathrm{L}, 90.6 \mu \mathrm{mol}, 1.0$ equiv) in dry $\mathrm{CH}_{2} \mathrm{Cl}_{2}(1.10 \mathrm{~mL})$ in a glass vial or a flask under an argon atmosphere to initiate the polymerization at room temperature $\left(24-26^{\circ} \mathrm{C}\right)$. During the polymerization, an aliquot of the reaction mixture $(\sim 40 \mu \mathrm{L})$ was taken and mixed with a small amount of benzoic acid. The aliquot was analyzed by ${ }^{1} \mathrm{H}$ NMR to determine the conversion of the monomer and by SEC to analyze the molar-mass distribution of the crude product. The sampling was conducted twice in this polymerization. After $3 \mathrm{~h} 47 \mathrm{~min}$, the reaction mixture was divided in two solutions with the same amount. Enough amount of benzoic acid (22.4 mg, $183 \mu \mathrm{mol}, 16.2$ equiv to TMnPG) was added to one of the solutions to neutralize TMnPG. PhCCSiMe $\mathrm{NEt}_{2}(31.5 \mathrm{mg}, 136 \mu \mathrm{mol}, 3.0$ equiv to the initial amount of $\mathrm{H}_{2} \mathrm{O}$ ) was added to both of the solutions to end-cap the propagating $\alpha$, $\omega$-bissilanol-terminated PDMS (PDMS- $\left.(\mathrm{OH})_{2}\right)$. After $3 \mathrm{~h} 40 \mathrm{~min}$, the completion of the end-capping reactions in both of the solutions were confirmed from ${ }^{1} \mathrm{H}$ NMR measurements. Then, the reaction mixture was concentrated under reduced pressure. The obtained oil was mixed/shaken with $\mathrm{MeCN}(3 \mathrm{~mL})$ and the upper layer was removed; the washing procedure 
with $\mathrm{MeCN}$ was repeated in total three times. The residue was diluted with toluene $(2 \mathrm{~mL})$ and concentrated in vacuo. The solvent remaining in the product was thoroughly removed in vacuo to obtain $\alpha, \omega$-bis[(phenylethynyl)dimethylsilyl]-terminated PDMS (PDMS- $\left.(\mathrm{CCPh})_{2}\right)\left(189.8 \mathrm{mg}, 71.0 \%\right.$ yield, $M_{\mathrm{n}, \mathrm{NMR}}=$ $6.02 \mathrm{kDa}, M_{\mathrm{n}, \mathrm{SEC}}=3.54 \mathrm{kDa}, \Xi_{\mathrm{M}}=1.08_{0}$ for the product obtained without benzoic acid; $209.9 \mathrm{mg}, 78.5 \%$ yield, $M_{\mathrm{n}, \mathrm{NMR}}=6.87 \mathrm{kDa}, M_{\mathrm{n}, \mathrm{SEC}}=3.84 \mathrm{kDa}, \bigoplus_{\mathrm{M}}=1.15_{2}$ for the product obtained with benzoic acid) as a colorless liquid.. ${ }^{1} \mathrm{H}$ NMR and ${ }^{29} \mathrm{Si}\left\{{ }^{1} \mathrm{H}\right\}$ NMR spectra of the product obtained with benzoic acid are shown in Figure 1.

\section{Synthesis of $\alpha, \omega$-bis[dimethyl(ethynyl)silyl]-terminated PDMS (PDMS-(CCH)2) ${ }^{\mathrm{S4}}$}

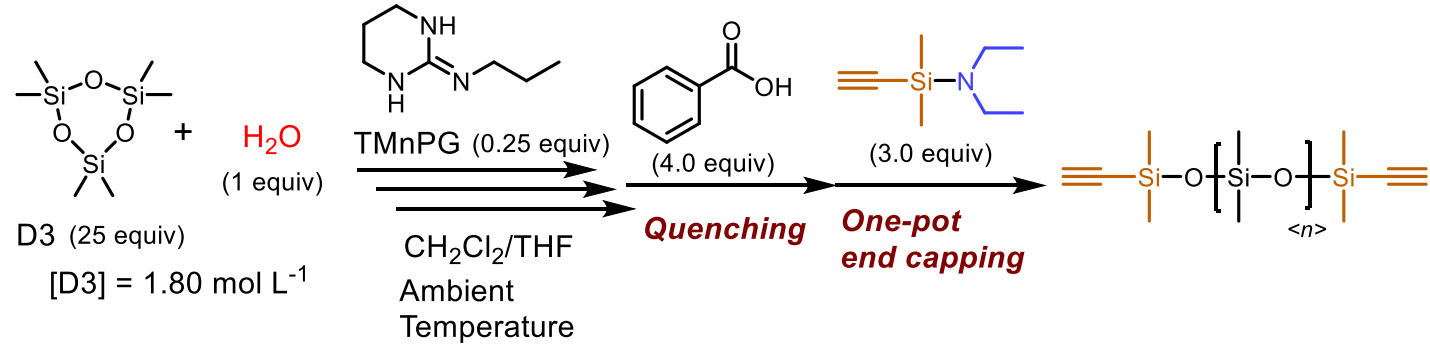

A toluene solution of TMnPG (100 mg mL $\mathrm{mL}^{-1}, 64.0 \mu \mathrm{L}, 45.3 \mu \mathrm{mol}, 0.25$ equiv) was added to a solution of D3 (1.01 g, 4.53 mmol, 25 equiv) and a THF solution of $\mathrm{H}_{2} \mathrm{O}\left(1 / 99\right.$ (v/v), $327 \mu \mathrm{L}, 181 \mu \mathrm{mol}, 1.0$ equiv) in dry $\mathrm{CH}_{2} \mathrm{Cl}_{2}$ $(2.19 \mathrm{~mL})$ in a glass vial or a flask under an argon atmosphere to initiate the polymerization at room temperature (24-26 $\left.{ }^{\circ} \mathrm{C}\right)$. During the polymerization, an aliquot of the reaction mixture $(\sim 40 \mu \mathrm{L})$ was taken and mixed with a small amount of benzoic acid. The aliquot was analyzed by ${ }^{1} \mathrm{H}$ NMR to determine the conversion of the monomer and by SEC to analyze the molar-mass distribution of the crude product. The sampling was conducted three times in this polymerization. After 3 h 14 min, $\mathrm{HCCSiMe}_{2} \mathrm{NEt}_{2}$ (37wt\% in xylene, $229 \mathrm{mg}, 546 \mu$ mol, 3.0 equiv) was added to the solution to end-cap the propagating PDMS- $(\mathrm{OH})_{2}$. After $3 \mathrm{~h} 7 \mathrm{~min}$, the completion of the end-capping reactions was confirmed from ${ }^{1} \mathrm{H}$ NMR measurements. Then, the reaction mixture was concentrated under reduced pressure. The obtained oil was purified in the same manner as that for PDMS- $(\mathrm{CCPh})_{2}$ to obtain a, $\omega$-bis[ethynyldimethylsilyl]-terminated PDMS (PDMS- $\left.(\mathrm{CCH})_{2}\right)\left(754.4 \mathrm{mg}, 72.5 \%\right.$ yield, $M_{\mathrm{n}, \mathrm{NMR}}=6.01 \mathrm{kDa}$, $\left.M_{\mathrm{n}, \mathrm{SEC}}=2.51 \mathrm{kDa}, \bigoplus_{\mathrm{M}}=1.09_{9}\right)$ as a colorless liquid. ${ }^{1} \mathrm{H} \mathrm{NMR}$ and ${ }^{29} \mathrm{Si}\left\{{ }^{1} \mathrm{H}\right\}$ NMR spectra of the product obtained with benzoic acid are shown in Figure 1.

\section{Synthesis of $\alpha$-trimethylsilyl- $\omega$-ethynyldimethylsilyl-terminated PDMS (PDMS-CCH) ${ }^{\mathrm{S} 12}$}

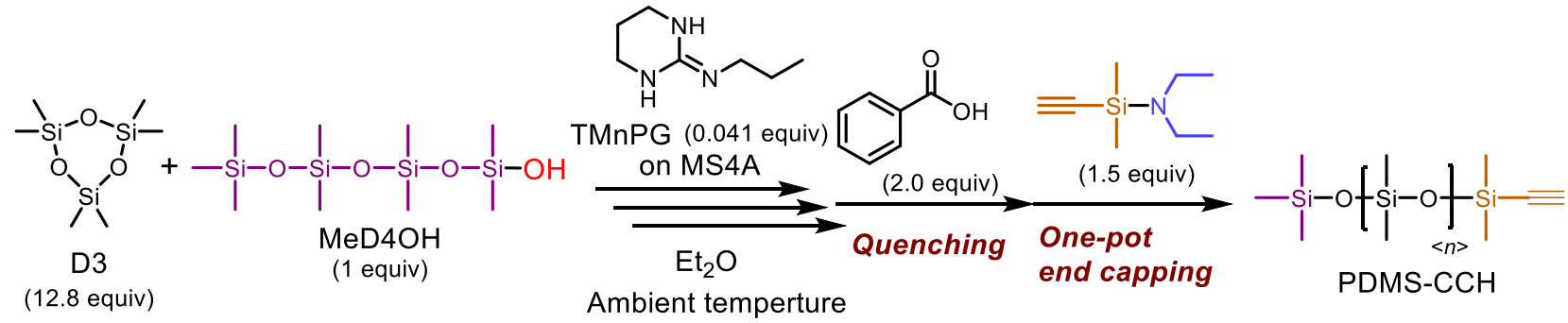

A toluene solution of TMnPG (100 mg mL $\mathrm{mL}^{-1}, 41.0 \mu \mathrm{L}, 29.0 \mu \mathrm{mol}, 0.041$ equiv) was added to a solution of D3 (2.02 g, $9.06 \mathrm{mmol}, 12.8$ equiv) and $\mathrm{MeD} 4 \mathrm{OH}\left(221 \mathrm{mg}, 708 \mu \mathrm{mol}, 1.0\right.$ equiv) in dry $\mathrm{Et}_{2} \mathrm{O}(5.03 \mathrm{~mL})$ in a glass vial under an argon atmosphere to initiate the polymerization at room temperature $\left(24-26{ }^{\circ} \mathrm{C}\right)$. During the polymerization, an aliquot of the reaction mixture $(\sim 40 \mu \mathrm{L})$ was taken and mixed with a small amount of benzoic acid. The aliquot was analyzed by ${ }^{1} \mathrm{H}$ NMR to determine the conversion of the monomer and by SEC to analyze 
the molar-mass distribution of the crude product. The sampling was conducted twice in this polymerization. After $16 \mathrm{~h} 49 \mathrm{~min}, \mathrm{HCCSiMe}_{2} \mathrm{NEt}_{2}$ (37wt\% in xylene, $447 \mathrm{mg}, 1.06 \mathrm{mmol}, 1.5$ equiv) was added to both of the solutions to end-cap the propagating PDMS. After $24 \mathrm{~h}$, the reaction mixture was concentrated under reduced pressure. The obtained oil was purified in the same manner as that for PDMS- $(\mathrm{CCPh})_{2}$ to obtain $\alpha$-trimethylsilyl- $\omega$-(ethynyldimethylsilyl)-terminated PDMS (PDMS-CCH) $\left(1.56 \mathrm{~g}, 68.0 \%\right.$ yield, $M_{\mathrm{n}, \mathrm{NMR}}=2.96$ $\left.\mathrm{kDa}, M_{\mathrm{n}, \mathrm{SEC}}=1.15 \mathrm{kDa}, \bigoplus_{\mathrm{M}}=1.11_{2}\right)$ as a colorless liquid. ${ }^{1} \mathrm{H}$ NMR and ${ }^{29} \mathrm{Si}\left\{{ }^{1} \mathrm{H}\right\}$ NMR spectra of the product obtained with benzoic acid are shown in Figure S5.

\section{Synthesis of $\alpha, \omega$-bis[ethynyldimethylsilyl]-terminated poly(dimethylsiloxane-co-allyl- (methyl)siloxane) (P(DMS-co-AMS)-(CCH)2 $)^{\mathrm{S} 1}$}

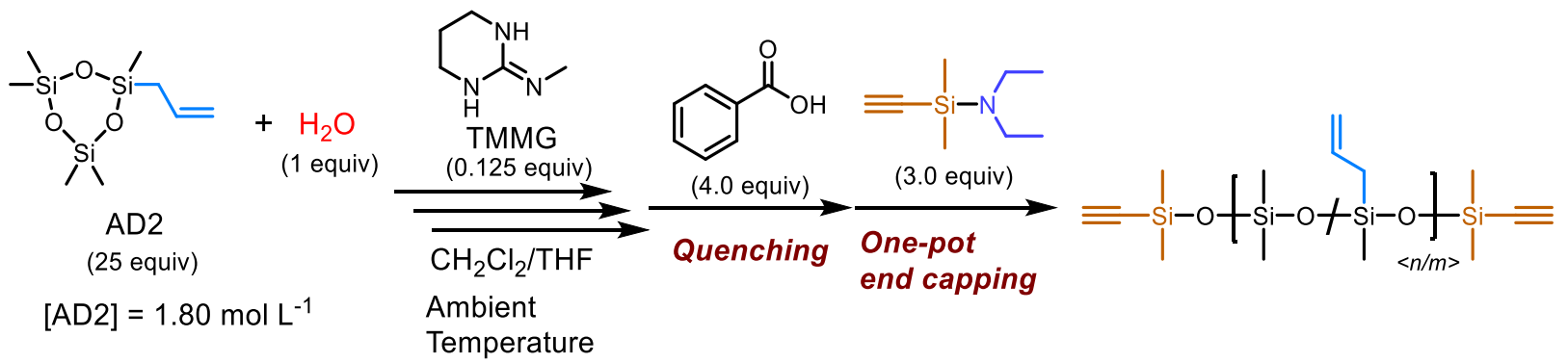

A THF solution of TMMG ( $60 \mathrm{mg} \mathrm{mL}^{-1}, 60.7 \mu \mathrm{L}, 32.2 \mu \mathrm{mol}, 0.125$ equiv) was added to a solution of AD2 $(1.77 \mathrm{~g}, 6.44 \mathrm{mmol}, 25$ equiv, a mixture with octamethylcyclotetrasiloxane (D4), AD2/D4 = 90.6/9.4 (w/w)) and a THF solution of $\mathrm{H}_{2} \mathrm{O}\left(1 / 99(\mathrm{v} / \mathrm{v}), 464 \mu \mathrm{L}, 258 \mu \mathrm{mol}, 1.0\right.$ equiv) in dry $\mathrm{CH}_{2} \mathrm{Cl}_{2}(3.11 \mathrm{~mL})$ in a glass vial under an argon atmosphere to initiate the polymerization at room temperature $\left(24-26^{\circ} \mathrm{C}\right)$. After $8 \mathrm{~h} 20 \mathrm{~min}$, the one-pot end-capping reaction was achieved by adding benzoic acid (126 mg, $1.03 \mathrm{mmol}, 4$ equiv) to quench the catalyst and $\mathrm{HCCSiMe}_{2} \mathrm{NEt}_{2}(331 \mathrm{mg}, 0.787 \mathrm{mmol}, 37 \mathrm{wt} \%$ in xylene, 3.05 equiv) to end-cap the polysiloxane. Then, the reaction mixture was concentrated under reduced pressure. The obtained oil was mixed/shaken with MeCN (10 $\mathrm{mL}$ ) and the upper layer was removed; the washing procedure with $\mathrm{MeCN}$ was repeated in total five times. The residue was diluted with toluene $(10 \mathrm{~mL})$ and concentrated in vacuo. The solvent remaining in the product was thoroughly removed in vacuo to obtain $\alpha, \omega$-bis[ethynyldimethylsilyl]-terminated poly[dimethylsiloxane-co-allyl(methyl)siloxane] (P(DMS-co-AMS)- $\left.(\mathrm{CCH})_{2}\right)\left(1.30 \mathrm{~g}, 78.9 \%\right.$ yield, $M_{\mathrm{n}, \mathrm{NMR}}=6.25$ $\left.\mathrm{kDa},\left(\left\langle X_{\mathrm{n}, \mathrm{D}} / X_{\mathrm{n}, \mathrm{A}}\right\rangle=49.4 / 24.0\right), M_{\mathrm{n}, \mathrm{SEC}}=3.07 \mathrm{kDa}, D_{\mathrm{M}}=1.148\right)$ as a colorless liquid. ${ }^{1} \mathrm{H}$ and ${ }^{29} \mathrm{Si}\left\{{ }^{1} \mathrm{H}\right\} \mathrm{NMR}$ spectra of the product are shown in Figure S3.

\section{Synthesis \\ of \\ $\alpha, \omega$-bis[ethynyldimethylsilyl]-terminated poly(dimethylsiloxane-co-(3-cyanopropyl)methylsiloxane) (P(DMS-co-CNPMS)-(CCH)2) ${ }^{\mathrm{S} 2}$}

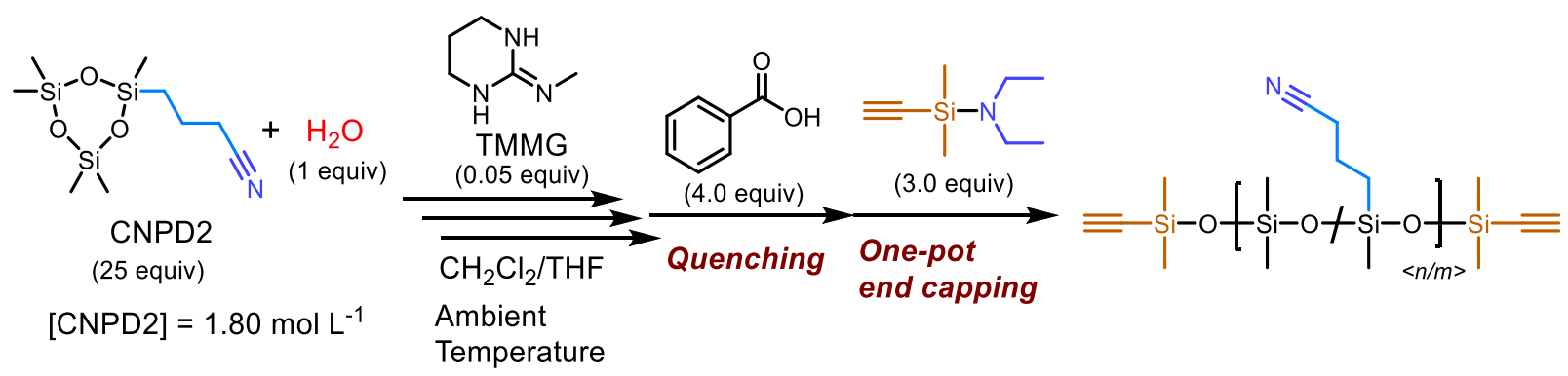

A THF solution of TMMG (60 mg mL $\mathrm{mL}^{-1}, 24.3 \mu \mathrm{L}, 12.9 \mu \mathrm{mol}, 0.05$ equiv) was added to a solution of CNPD2 
(1.77 g, 6.44 mmol, 25 equiv) and a THF solution of $\mathrm{H}_{2} \mathrm{O}\left(1 / 99\right.$ (v/v), $464 \mu \mathrm{L}, 258 \mu \mathrm{mol}, 1.0$ equiv) in dry $\mathrm{CH}_{2} \mathrm{Cl}_{2}$ $(3.11 \mathrm{~mL})$ in a glass vial under an argon atmosphere to initiate the polymerization at room temperature $\left(24-26^{\circ} \mathrm{C}\right)$. During the polymerization, an aliquot of the reaction mixture $(\sim 40 \mu \mathrm{L})$ was taken and mixed with a small amount of benzoic acid. The aliquot was analyzed by ${ }^{1} \mathrm{H}$ NMR to determine the conversion of the monomer and by SEC to analyze the molar-mass distribution of the crude product. After $4 \mathrm{~h} 29 \mathrm{~min}$, the one-pot end-capping reaction was achieved by adding benzoic acid (126 mg, $1.03 \mathrm{mmol}, 4$ equiv) to quench the catalyst and $\mathrm{HCCSiMe}_{2} \mathrm{NEt}_{2}$ (355 mg, $0.844 \mathrm{mmol}, 37 \mathrm{wt} \%$ in xylene, 3.28 equiv) to end-cap the polysiloxane. Then, the reaction mixture was concentrated under reduced pressure. The obtained oil was mixed/shaken with $\mathrm{MeCN} / \mathrm{H}_{2} \mathrm{O}(7 / 3(\mathrm{v} / \mathrm{v}), 10 \mathrm{~mL})$ and the upper layer was removed; the washing procedure with $\mathrm{MeCN} / \mathrm{H}_{2} \mathrm{O}$ was repeated in total five times. The residue was diluted with toluene $(10 \mathrm{~mL})$ and concentrated in vacuo. The solvent remaining in the product was thoroughly removed in vacuo to obtain $\alpha, \omega$-bis[ethynyldimethylsilyl]-terminated poly[dimethylsiloxane-co-3-cyanopropyl(methyl)siloxane] $\left(\mathrm{P}\left(\mathrm{DMS}-c o\right.\right.$-CNPMS) $\left(1.11 \mathrm{~g}, 61.0 \%\right.$ yield, $M_{\mathrm{n}, \mathrm{NMR}}=$ $\left.6.42 \mathrm{kDa}\left(\left\langle X_{\mathrm{n}, \mathrm{D}} / X_{\mathrm{n}, \mathrm{CNP}}\right\rangle=45.2 / 22.7\right), M_{\mathrm{n}, \mathrm{SEC}}=3.98 \mathrm{kDa}, \emptyset_{\mathrm{M}}=1.069\right)$ as a colorless liquid. ${ }^{1} \mathrm{H}$ and ${ }^{29} \mathrm{Si}\left\{{ }^{1} \mathrm{H}\right\} \mathrm{NMR}$ spectra of the product are shown in Figure S4.

\section{Attempt of the synthesis of alkynyl-terminated PDMS by the conventional anionic ROP of D3 initiated by Me3SiOLi}

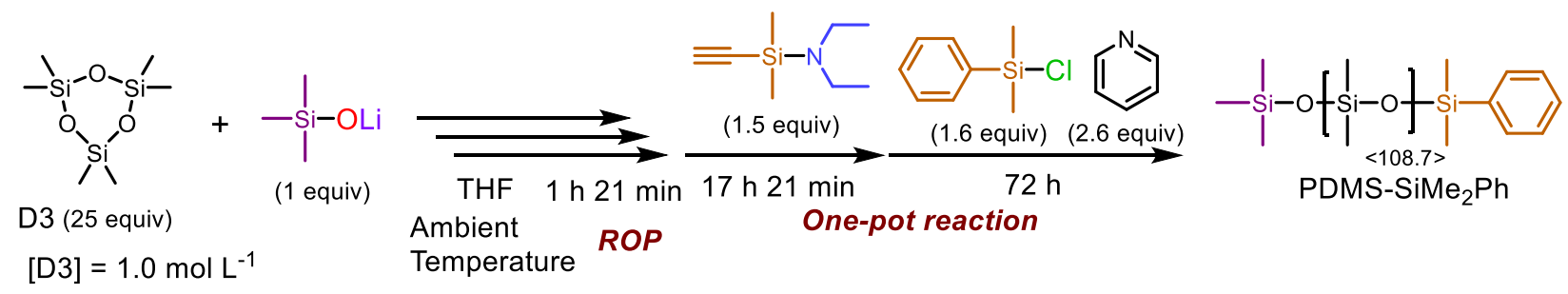

D3 $(295 \mathrm{mg}, 1.33 \mathrm{mmol})$ and dry THF $(0.95 \mathrm{~mL})$ was added to a vial under an argon atmosphere. $\mathrm{Me}_{3} \mathrm{SiOLi}$ $\left(0.375 \mathrm{~mL}, 13.6 \mathrm{mg} \mathrm{mL}^{-1}\right.$ in $\left.\mathrm{THF}, 53 \mu \mathrm{mol}\right)$ was added to initiate the polymerization at room temperature $\left(\sim 25^{\circ} \mathrm{C}\right)$. During the polymerization, in total $8.5 \mathrm{wt} \%$ of the reaction mixture was taken to check the progress of the polymerization. After stirring for $1 \mathrm{~h} 21 \mathrm{~min}$, the reaction mixture was divided into two solutions with the same weight. $\mathrm{HCCSiMe}_{2} \mathrm{NEt}_{2}(30.6 \mathrm{mg}, 72.8 \mu \mathrm{mol}, 37 \mathrm{wt} \%$ in xylene, 1.5 equiv) was added to one of the solutions. Then, the solution was stirred for $17 \mathrm{~h} 21 \mathrm{~min}$. Pyridine (10.0 $\mu \mathrm{L}, 124 \mu \mathrm{mol}, 2.6$ equiv) and $\mathrm{PhSiMe}_{2} \mathrm{Cl}$ (13.3 $\mu \mathrm{L}, 79.5 \mu \mathrm{mol}, 1.6$ equiv) were added to the reaction mixture. Then, the solution was stirred for 3 days at room temperature. The reaction mixture was concentrated, washed with $\mathrm{MeCN}(5 \mathrm{~mL})$ five times. The residue was dissolved in toluene $(5 \mathrm{~mL})$ and concentrated in vacuo to obtain $\alpha$-trimethylsilyl- $\omega$-dimethy(phenyl)silyl-terminated PDMS (233 mg, y. $76.0 \%, M_{\mathrm{n}, \mathrm{NMR}}=8.29 \mathrm{kDa},\left\langle X_{\mathrm{n}, \mathrm{D}}>=\right.$ 108.7, $\left.M_{\mathrm{n}, \mathrm{SEC}}=3.31 \mathrm{kDa}, \bigoplus_{\mathrm{M}}=1.08_{5}\right)$ as a colorless liquid. ${ }^{1} \mathrm{H}$, and ${ }^{29} \mathrm{Si}\left\{{ }^{1} \mathrm{H}\right\}$ NMR spectra of the product are shown in Figure S6. 


\section{Huisgen reaction for alkynylsilyl-terminated polysiloxanes (Table 2)}
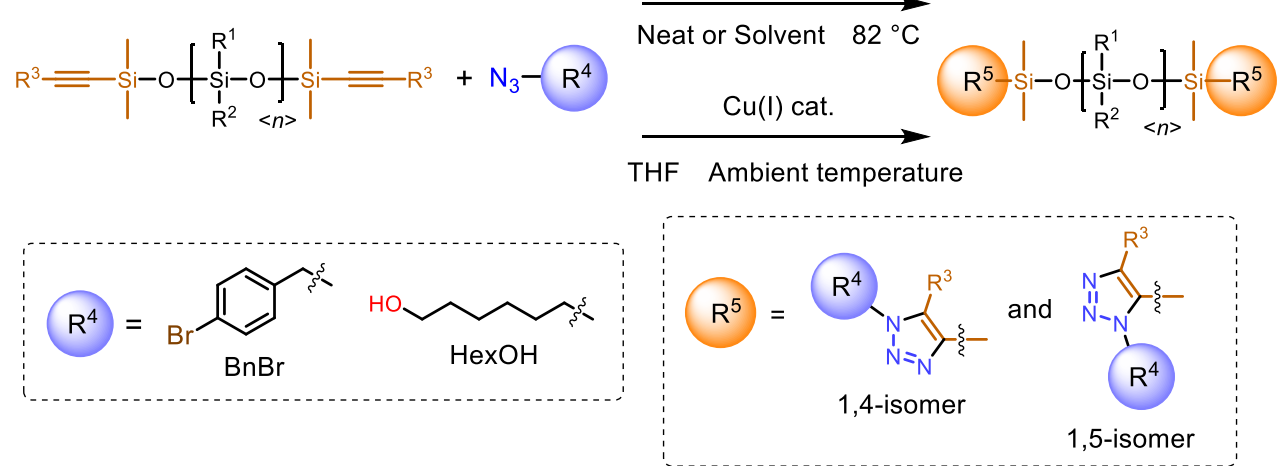

(Non-catalytic condition, Table 2, entries 1-6) Polysiloxanes with alkynylsilyl groups (PDMS-(CCPh)2, PDMS- $(\mathrm{CCH})_{2}, \mathrm{P}(\mathrm{DMS}-\mathrm{co}-\mathrm{CNPMS})-(\mathrm{CCH})_{2}$, and $\left.\mathrm{P}(\mathrm{DMS}-\mathrm{co}-\mathrm{AMS})-(\mathrm{CCH})_{2}\right)$, azido compounds $\left(\mathrm{N}_{3} \mathrm{BnBr}\right.$ or $\mathrm{N}_{3} \mathrm{HexOH}$ ), and dry solvent (toluene or xylene) were mixed in a glass tube with a Teflon screw (Ace pressure tube bushing type, Front seal) under argon atmosphere. The tube was heated at $82{ }^{\circ} \mathrm{C}$. The reaction mixture was concentrated under reduced pressure. The residue was mixed/shaken with MeCN (1 mL) for PDMS and $\mathrm{P}\left(\mathrm{DMS}-\mathrm{co}\right.$-AMS) or $\mathrm{MeCN} / \mathrm{H}_{2} \mathrm{O}(2 / 1(\mathrm{v} / \mathrm{v}), 1 \mathrm{~mL})$ for P(DMS-co-CNPMS) and the upper layer was removed. The washing procedure was repeated several times. The residue was diluted with toluene or 1,4-dioxane $(1 \mathrm{~mL})$ and concentrated in vасио. The solvent remaining in the product was thoroughly removed in vacuo to obtain polysiloxanes with converted terminal structures. ${ }^{1} \mathrm{H}$ and ${ }^{29} \mathrm{Si}\left\{{ }^{1} \mathrm{H}\right\}$ NMR spectra of the product are shown in Figures S7-S10.

For example, for the reaction shown in Table 2, entry 2, PDMS- $(\mathrm{CCH})_{2}\left(100 \mathrm{mg}, M_{\mathrm{n}, \mathrm{NMR}}=6.01 \mathrm{kDa}, M_{\mathrm{n}, \mathrm{SEC}}=\right.$ $2.73 \mathrm{kDa}, \emptyset_{\mathrm{M}}=1.10_{1}, 16.6 \mu$ mol-ethynyl group), $\mathrm{N}_{3} \mathrm{BnBr}(21.1 \mathrm{mg}, 99.5 \mu \mathrm{mol}, 6$ equiv), and toluene (100 $\mu \mathrm{L})$ were mixed in the tube. The reaction was continued for $16.5 \mathrm{~h}$. After the purification using $\mathrm{MeCN}$, the adducts of PDMS- $(\mathrm{CCH})_{2}$ and $\mathrm{N}_{3} \mathrm{BnBr}\left(72.1 \mathrm{mg}, 67.4 \%\right.$ yield, $\left.M_{\mathrm{n}, \mathrm{SEC}}=2.91 \mathrm{kDa}, \nexists_{\mathrm{M}}=1.10_{1}\right)$ was obtained as a colorless liquid. ${ }^{1} \mathrm{H}$ and ${ }^{29} \mathrm{Si}\left\{{ }^{1} \mathrm{H}\right\}$ NMR spectra of the product are shown in Figure $\mathrm{S} 6$.

(Catalytic condition, Table 2, entries 7-11) The catalyst A was prepared by mixing $\mathrm{CuBr}(32.1 \mathrm{mg}), \mathrm{Et}_{3} \mathrm{~N}$ (45.5 $\mathrm{mg})$, and dry THF $(15 \mathrm{~mL})$ under an argon atmosphere. The catalyst B was prepared by mixing $\mathrm{CuBr}(20.4 \mathrm{mg})$, PMDETA $(53.9 \mathrm{mg})$, and dry THF $(7.1 \mathrm{~mL})$ under an argon atmosphere. The reaction was initiated by adding the solution of the catalyst A or B to the mixture of the polysiloxanes with alkynylsilyl groups (PDMS- $(\mathrm{CCH})_{2}$ and $\left.\mathrm{P}(\mathrm{DMS} \text {-co-AMS)-(CCH })_{2}\right)$ and azido compounds $\left(\mathrm{N}_{3} \mathrm{BnBr}\right.$ or $\left.\mathrm{N}_{3} \mathrm{HexOH}\right)$ in a glass vial under argon atmosphere. After the completion of the reaction, the reaction mixture was concentrated under reduced pressure. The crude product was dissolved in hexane. The resulting solution was filtered using a SARTORIUS syringe filter (Mini Sarto SRP, pore size $=0.2 \mu \mathrm{m}$ ). The filtrate was concentrated under reduced pressure. The obtained oil was purified with the same procedures as the products obtained by the non-catalytic conditions. ${ }^{1} \mathrm{H}$ and ${ }^{29} \mathrm{Si}\left\{{ }^{1} \mathrm{H}\right\} \mathrm{NMR}$ spectra of the product are shown in Figures S11-S13.

For example, for the reaction shown in Table 2 , entry 7 , the solution of catalyst $\mathrm{A}(89 \mu \mathrm{L})$ was added to a mixture of PDMS- $(\mathrm{CCH})_{2}\left(80 \mathrm{mg}, M_{\mathrm{n}, \mathrm{NMR}}=6.01 \mathrm{kDa}, M_{\mathrm{n}, \mathrm{SEC}}=2.73 \mathrm{kDa}, \bigoplus_{\mathrm{M}}=1.10_{1}, 26.6 \mu\right.$ mol-ethynyl group $)$ and $\mathrm{N}_{3} \mathrm{BnBr}(16.9 \mathrm{mg}, 79.9 \mu \mathrm{mol}, 6$ equiv) under argon atmosphere at room temperature. The reaction was continued for $43.5 \mathrm{~h}$. After the purification, $\alpha, \omega$-bis[(1-(4-bromobenzyl)-4-triazolyl)dimethylsilyl]-terminated 
PDMS (56.5 mg, 66.0\% yield, $\left.M_{\mathrm{n}, \mathrm{SEC}}=2.93 \mathrm{kDa}, \bigoplus_{\mathrm{M}}=1.08_{1}\right)$ as a colorless liquid. ${ }^{1} \mathrm{H}$ and ${ }^{29} \mathrm{Si}\left\{{ }^{1} \mathrm{H}\right\} \mathrm{NMR}$ spectra of the product are shown in Figure S11. 
Determination of number-average degree of polymerization $\left(<X_{n}>\right)$ and $M_{n, N M R}$ of the polysiloxane using ${ }^{1} \mathrm{H}$ NMR spectroscopy.

The values of number-average degree of polymerization $\left(<X_{\mathrm{n}}>\right)$ and $M_{\mathrm{n}}\left(M_{\mathrm{n}, \mathrm{NMR}}\right)$ for the synthesized polysiloxanes were determined using ${ }^{1} \mathrm{H}$ NMR spectroscopy.

Index ' $\mathrm{Y}$ ' for $<X_{\mathrm{n}, \mathrm{Y}}>$ are defined as:

$\mathrm{D}=$ dimethylsiloxane units;

$\mathrm{A}=$ allyl(methyl) siloxane units.

$\mathrm{CNP}=3$-cyanopropyl(methyl)siloxane units;

The integral values of peak $\mathrm{x}$ in ${ }^{1} \mathrm{H}$ NMR spectra are written as $I_{\mathrm{x}}$.

For PDMS with $\alpha, \omega$-bis[dimethyl(phenylethynyl)silyl] (PDMS- $\left.(\mathrm{CCPh})_{2}\right)$ and $\alpha, \omega$-bis[ethynyldimethylsilyl] groups (PDMS- $\left.(\mathrm{CCH})_{2}\right)$ : The peaks in Figure 1 were used for the calculation.

$$
\begin{aligned}
& <X_{\mathrm{n}, \mathrm{D}}>=\left(I_{\mathrm{a}-\mathrm{d}} / 6\right) /\left(I_{\mathrm{e}} / 12\right) \\
& M_{\mathrm{n}, \mathrm{NMR}}=74.154<X_{\mathrm{n}, \mathrm{D}}>+M_{\text {terminal }}
\end{aligned}
$$

( $\alpha, \omega$-bis[dimethyl(phenylethynyl)silyl] groups, $M_{\text {terminal }}=334.57 ; \alpha, \omega$-bis[ethynyldimethylsilyl] groups, $M_{\text {terminal }}=$ 182.37)

For PDMS with $\alpha$-trimethylsilyl- $\omega$-ethynyldimethylsilyl groups (PDMS-CCH): The peaks in Figure S5 were used for the calculation.

$$
\begin{aligned}
& <X_{\mathrm{n}, \mathrm{D}}>=\left(\left(I_{\mathrm{a}-\mathrm{d}}+I_{\mathrm{f}-\mathrm{h}}-1.5 I_{\mathrm{e}}\right) / 6\right) /\left(I_{\mathrm{e}} / 6\right) \\
& M_{\mathrm{n}, \mathrm{NMR}}=74.154<X_{\mathrm{n}, \mathrm{D}}>+M_{\text {terminal }}
\end{aligned}
$$

( $\alpha$-trimethylsilyl- $\omega$-ethynyldimethylsilyl groups, $M_{\text {terminal }}=172.37$ )

For P(DMS-co-AMS) with $\alpha, \omega$-bis[ethynyldimethylsilyl] groups: The peaks in Figure S3 were used for the calculation.

$$
\begin{aligned}
& <X_{\mathrm{n}, \mathrm{A}}>=\left(I_{\mathrm{e}+\mathrm{f}} / 2\right) /\left(I_{\mathrm{g}} / 12\right) \\
& <X_{\mathrm{n}, \mathrm{D}}>=\left(\left(I_{\mathrm{a}+\mathrm{b}}-1.5 I_{\mathrm{e}+\mathrm{f}}\right) / 6\right) /\left(I_{\mathrm{g}} / 12\right) \\
& M_{\mathrm{n}, \mathrm{NMR}}=74.154<X_{\mathrm{n}, \mathrm{D}}>+100.19<X_{\mathrm{n}, \mathrm{A}}>+M_{\text {terminal }}
\end{aligned}
$$

$\left(\alpha, \omega\right.$-bis[ethynyldimethylsilyl] groups, $\left.M_{\text {terminal }}=182.37\right)$

For P(DMS-co-CNPMS) with $\alpha, \omega$-bis[ethynyldimethylsilyl] groups: The peaks in Figure S4 were used for the calculation.

$$
\begin{aligned}
& <X_{\mathrm{n}, \mathrm{CNP}}>=\left(I_{\mathrm{c}} / 2\right) /\left(I_{\mathrm{f}} / 12\right) \\
& <X_{\mathrm{n}, \mathrm{D}}>=\left(\left(I_{\mathrm{a}+\mathrm{b}}-1.5 I_{\mathrm{c}}\right) / 6\right) /\left(I_{\mathrm{f}} / 12\right) \\
& M_{\mathrm{n}, \mathrm{NMR}}=74.154<X_{\mathrm{n}, \mathrm{D}}>+127.22<X_{\mathrm{n}, \mathrm{CNP}}>+M_{\text {terminal }}
\end{aligned}
$$

$\left(\alpha, \omega\right.$-bis[ethynyldimethylsilyl] groups, $\left.M_{\text {terminal }}=182.37\right)$ 


\section{NMR spectra, molar mass distributions, MALDI-TOF MS spectra of the products}

Positive-ion MALDI-TOF MS spectra of the synthesized polysiloxanes measured in linear mode using a trans-2-[3-(4-tert-butylphenyl)-2-methyl-2-propenylidene]malononitrile (DCTB) matrix and sodium trifluoroacetate as the cationization agent. The circles in the right spectrum show the theoretical $\mathrm{m} / \mathrm{z}$ values for the polymers with degrees of polymerization of $n$ and $m$. For P(DMS-co-AMS) and $\mathrm{P}$ (DMS-co-CNPMS), the circles with lower deviation from $n / m=2 / 1$ are displayed at higher positions.

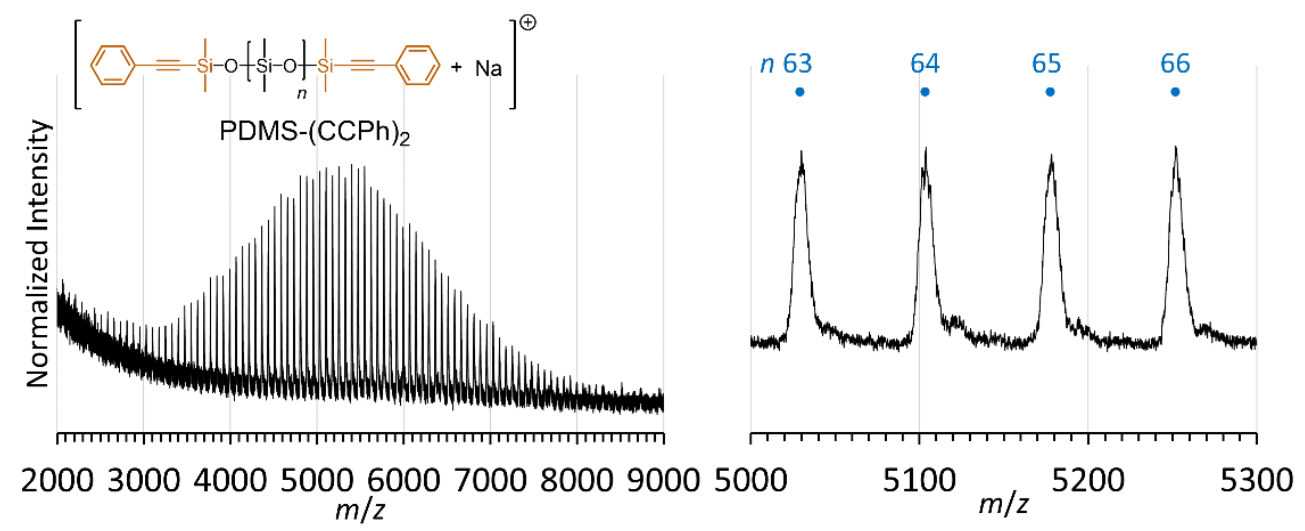

Figure S1. Positive-ion MALDI-TOF MS spectra of PDMS end-functionalized with bis[(phenylethynyl)dimethylsilyl] groups (PDMS- $(\mathrm{CCPh})_{2}, M_{\mathrm{n}, \mathrm{NMR}}=6.02 \mathrm{kDa}$ and $\left.\emptyset_{\mathrm{M}}=1.08_{0}\right)$ (Table 1 entry 1$)$.

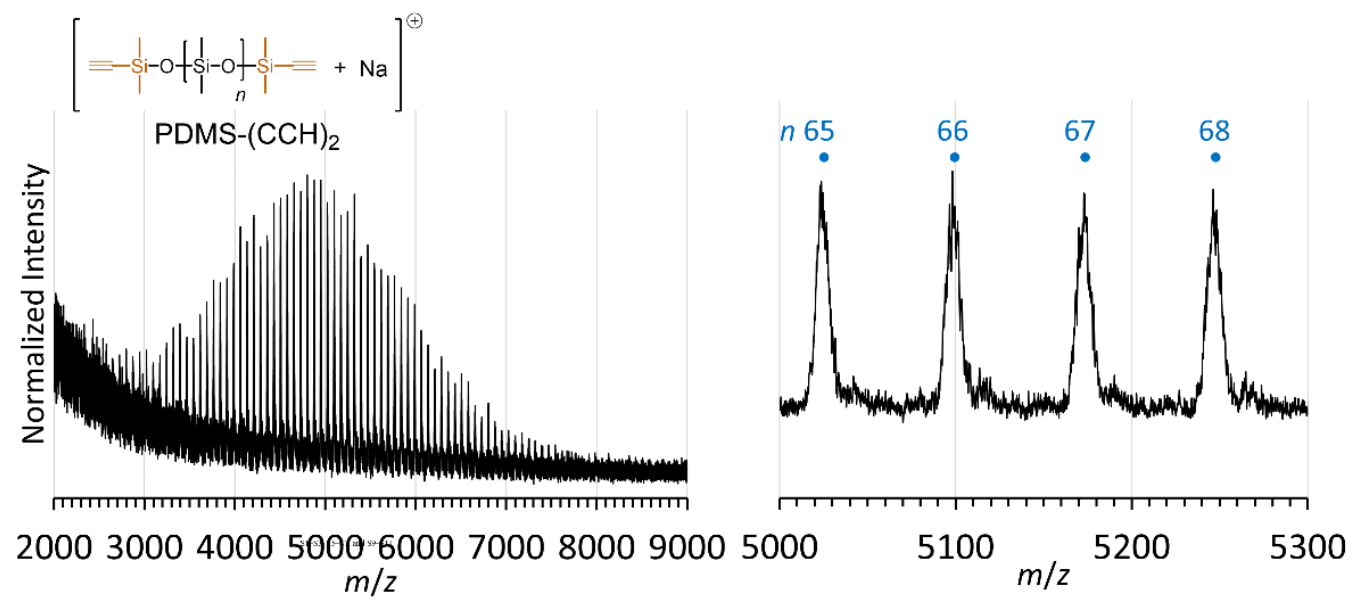

Figure S2. Positive-ion MALDI-TOF MS spectra of PDMS end-functionalized with bis[(ethynyl)dimethylsilyl] groups (PDMS- $(\mathrm{CCH})_{2}, M_{\mathrm{n}, \mathrm{NMR}}=6.01 \mathrm{kDa}$ and $\left.\bigoplus_{\mathrm{M}}=1.09_{9}\right)$ (Table 1, entry 2$)$. 

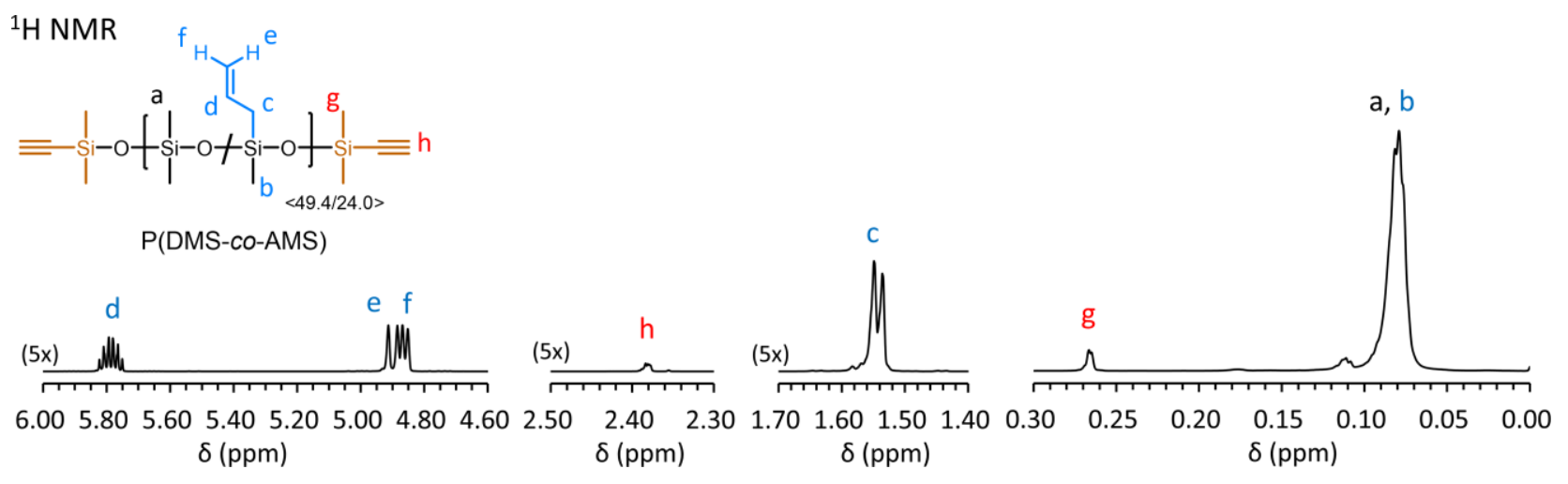
$\delta(\mathrm{ppm})$
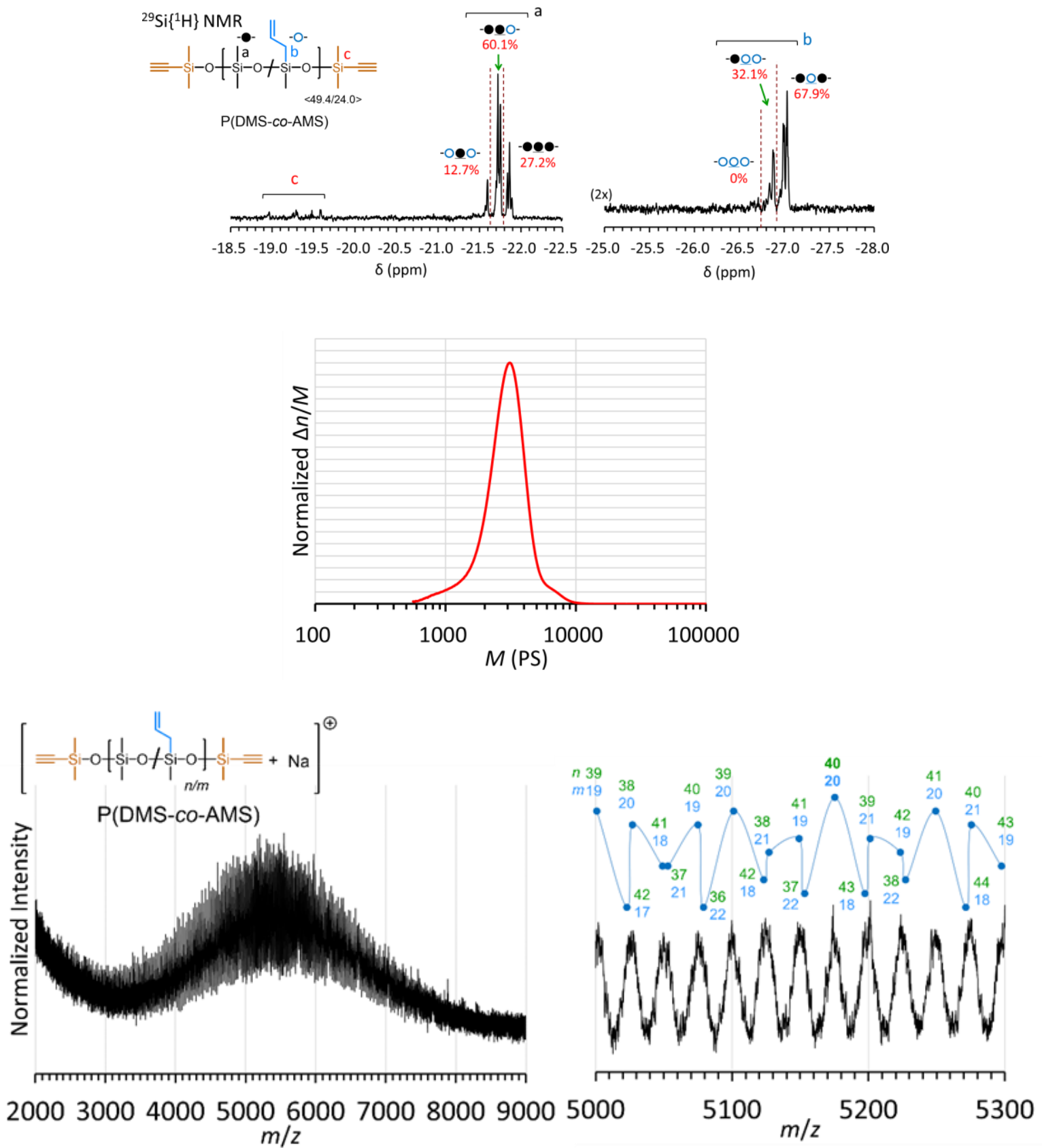

Figure S3. ${ }^{1} \mathrm{H}$ NMR and ${ }^{29} \mathrm{Si}\left\{{ }^{1} \mathrm{H}\right\}$ NMR spectra, molar-mass distribution, and positive-ion MALDI-TOF MS spectra of poly[dimethylsiloxane-co-allyl(methyl)siloxane] end-functionalized with dimethyl(ethynyl)silyl groups $\left(\mathrm{P}(\mathrm{DMS}-\mathrm{co}-\mathrm{AMS})-(\mathrm{CCH})_{2}, M_{\mathrm{n}, \mathrm{NMR}}=6.25 \mathrm{kDa},\left\langle X_{\mathrm{n}, \mathrm{D}} / X_{\mathrm{n}, \mathrm{A}}\right\rangle=49.4 / 24.0\right.$, and $\left.\bigoplus_{\mathrm{M}}=1.14_{8}\right)$ (Table 1, entry 5). 

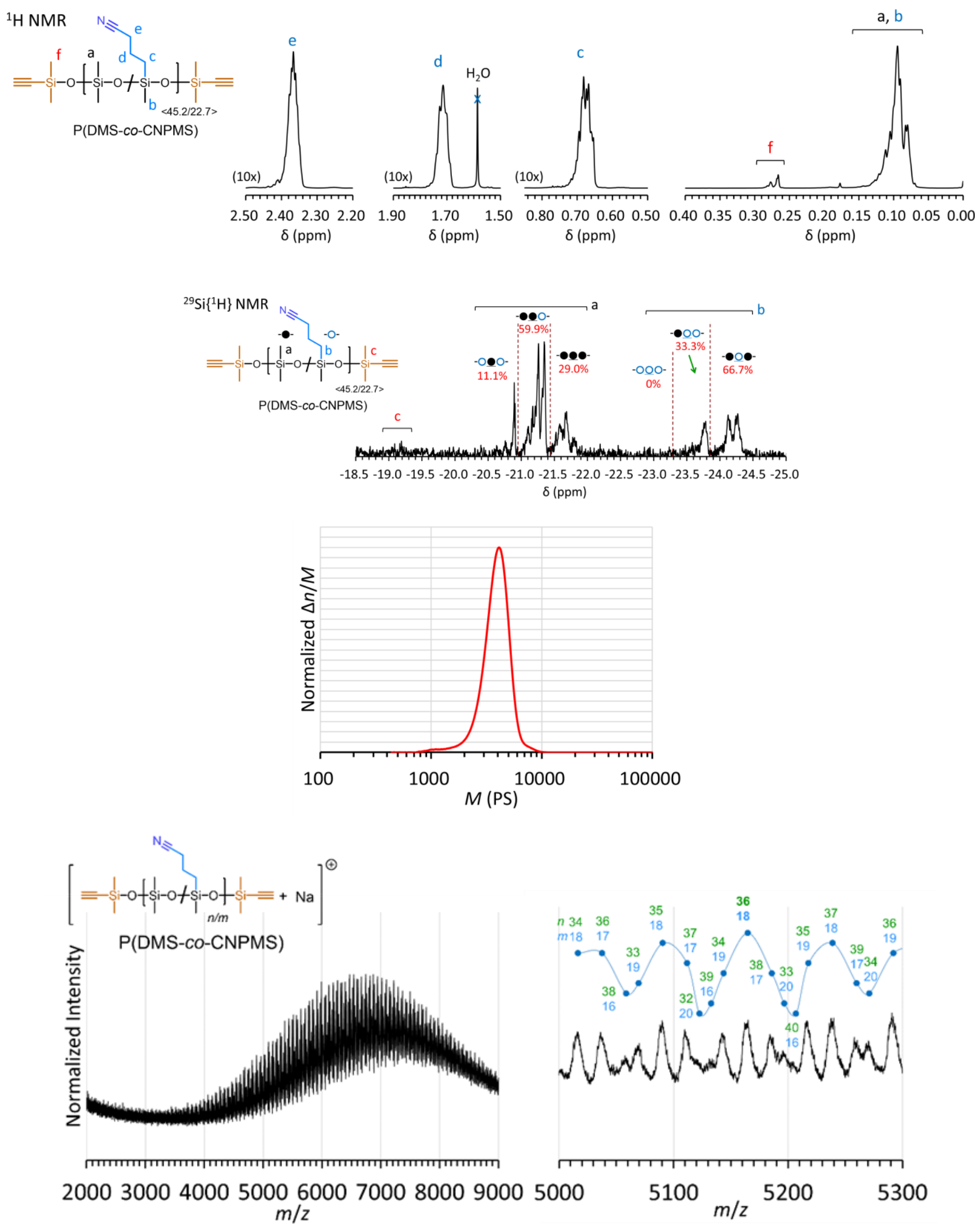

Figure S4. ${ }^{1} \mathrm{H}$ NMR and ${ }^{29} \mathrm{Si}\left\{{ }^{1} \mathrm{H}\right\}$ NMR spectra, molar-mass distribution, and positive-ion MALDI-TOF MS spectra of poly[dimethylsiloxane-co-(3-cyanopropyl)methylsiloxane] end-functionalized with dimethyl(ethynyl)silyl groups (P(DMS-co-CNPMS)-(CCH) $2, M_{\mathrm{n}, \mathrm{NMR}}=6.42 \mathrm{kDa},\left\langle X_{\mathrm{n}, \mathrm{D}} / X_{\mathrm{n}, \mathrm{CNP}}\right\rangle=45.2 / 22.7$, and $Ð_{\mathrm{M}}=1.06_{9}$ ) (Table 1, entry 6). 

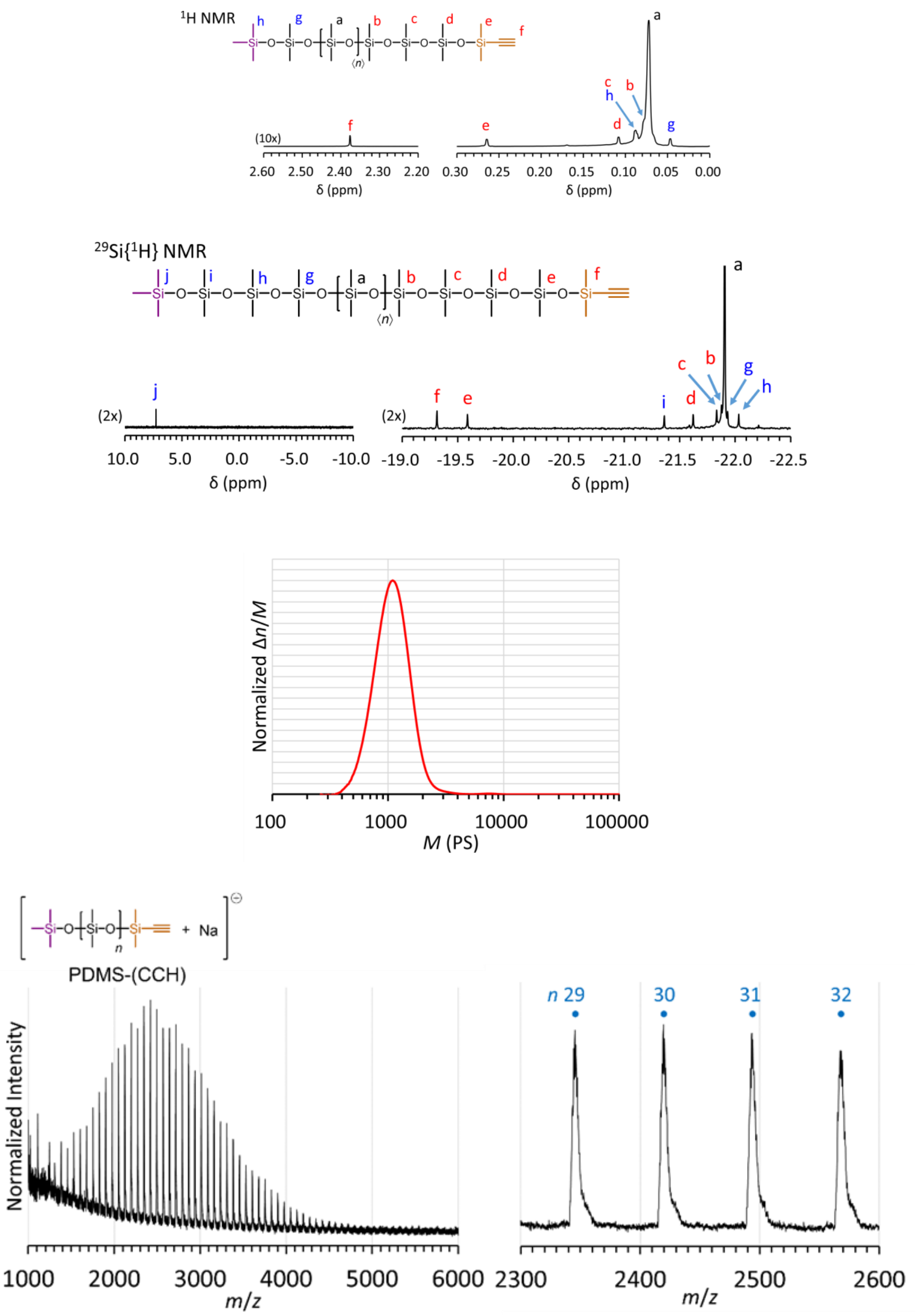

Figure S5. ${ }^{1} \mathrm{H}$ NMR and ${ }^{29} \mathrm{Si}\left\{{ }^{1} \mathrm{H}\right\}$ NMR spectra, molar-mass distribution, and positive-ion MALDI-TOF MS spectra of $\alpha$-trimethylsilyl- $\omega$-dimethyl(ethynyl)silyl-PDMS $\left(M_{\mathrm{n}, \mathrm{NMR}}=2.96 \mathrm{kDa},\left\langle X_{\mathrm{n}, \mathrm{D}}\right\rangle=38.2\right.$, and $\left.\emptyset_{\mathrm{M}}=1.11_{2}\right)$ (Table 1, entry 4). 

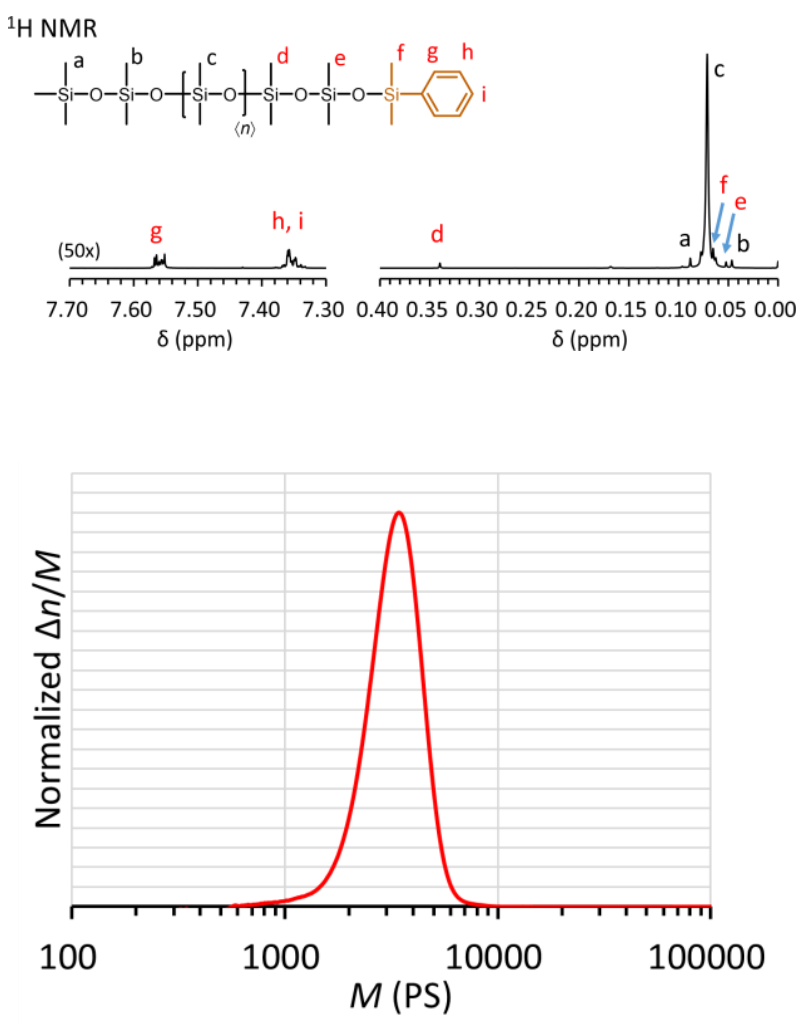

Figure S6. ${ }^{1} \mathrm{H}$ NMR spectrum of $\alpha$-trimethylsilyl- $\omega$-dimethyl(phenyl)silyl-PDMS obtained from the polymerization of $\mathrm{D} 3$ using $\mathrm{Me}_{3} \mathrm{SiOLi}$ as an initiator and $\mathrm{HCCSiMe}_{2} \mathrm{NEt}_{2}$ and $\mathrm{PhSiMe}_{2} \mathrm{Cl}$ as end-capping agents (Scheme 3, $M_{\mathrm{n}, \mathrm{NMR}}=8.29 \mathrm{kDa},\left\langle X_{n}\right\rangle=108.7$, and $\bigoplus_{\mathrm{M}}=1.08_{5}$ ). 

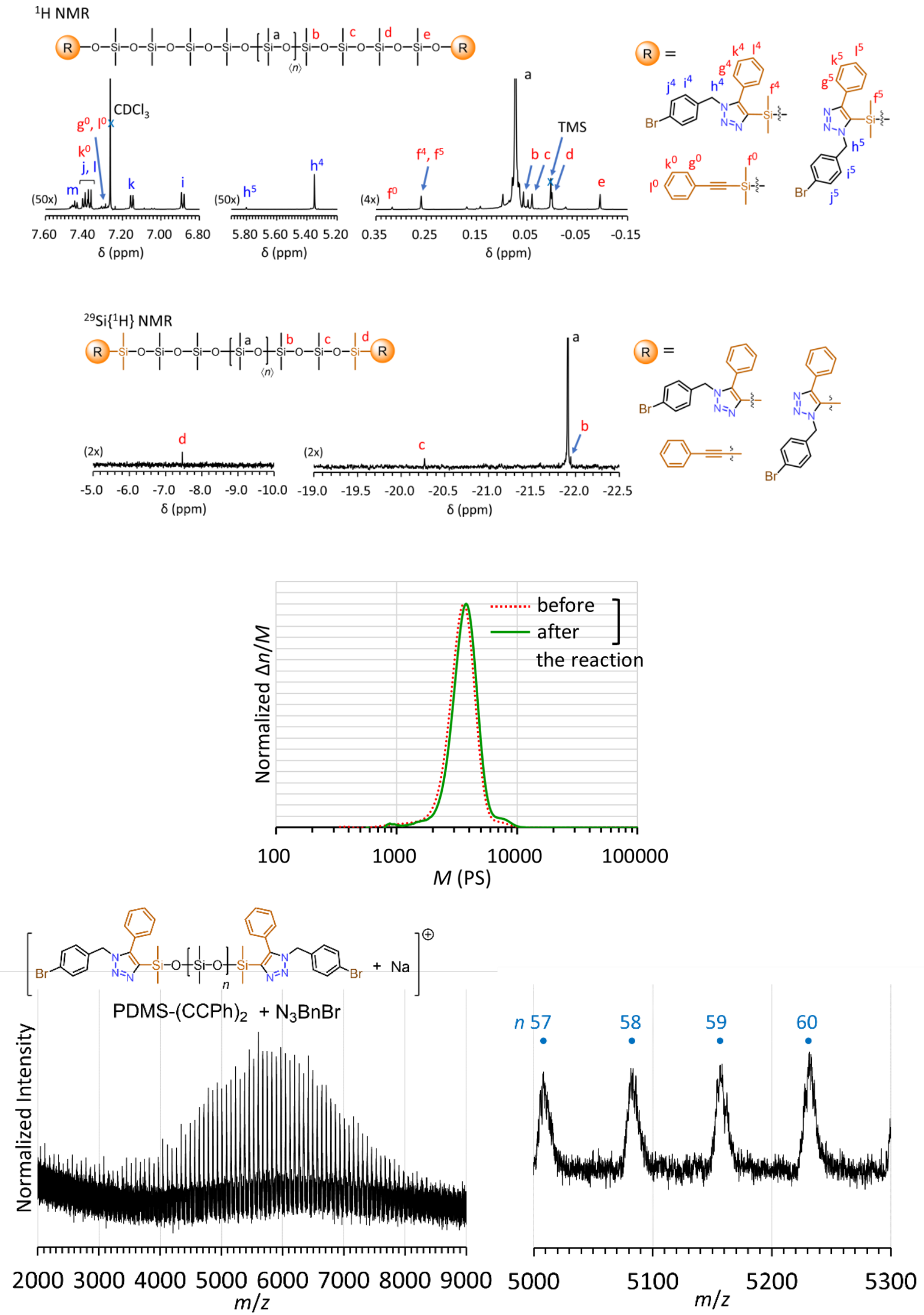

Figure S7. ${ }^{1} \mathrm{H}$ NMR and ${ }^{29} \mathrm{Si}\left\{{ }^{1} \mathrm{H}\right\}$ NMR spectra, molar-mass distribution, and positive-ion MALDI-TOF MS spectra of the product $\left(M_{\mathrm{n}, \mathrm{SEC}}=3.80 \mathrm{kDa}, D_{\mathrm{M}}=1.08_{2}\right)$ of the reaction between PDMS- $(\mathrm{CCPh})_{2}\left(M_{\mathrm{n}, \mathrm{SEC}}=3.54\right.$ $\mathrm{kDa}, \bigoplus_{\mathrm{M}}=1.08_{0}$ ) and $\mathrm{N}_{3} \mathrm{BnBr}$ under the non-catalytic condition (Table 2, entry 1). 
${ }^{1} \mathrm{H}$ NMR
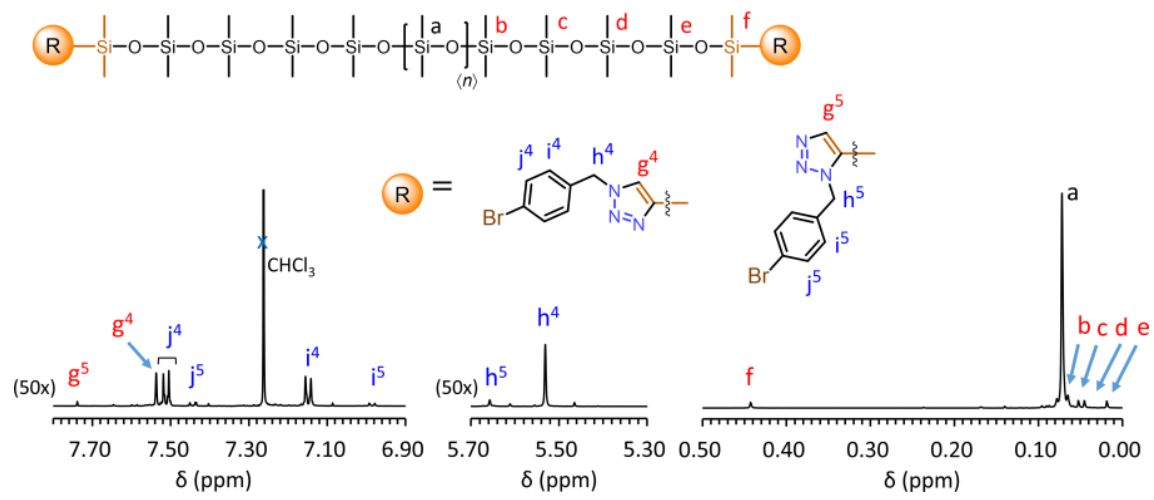

${ }^{29} \mathrm{Si}\left\{{ }^{1} \mathrm{H}\right\} \mathrm{NMR}$
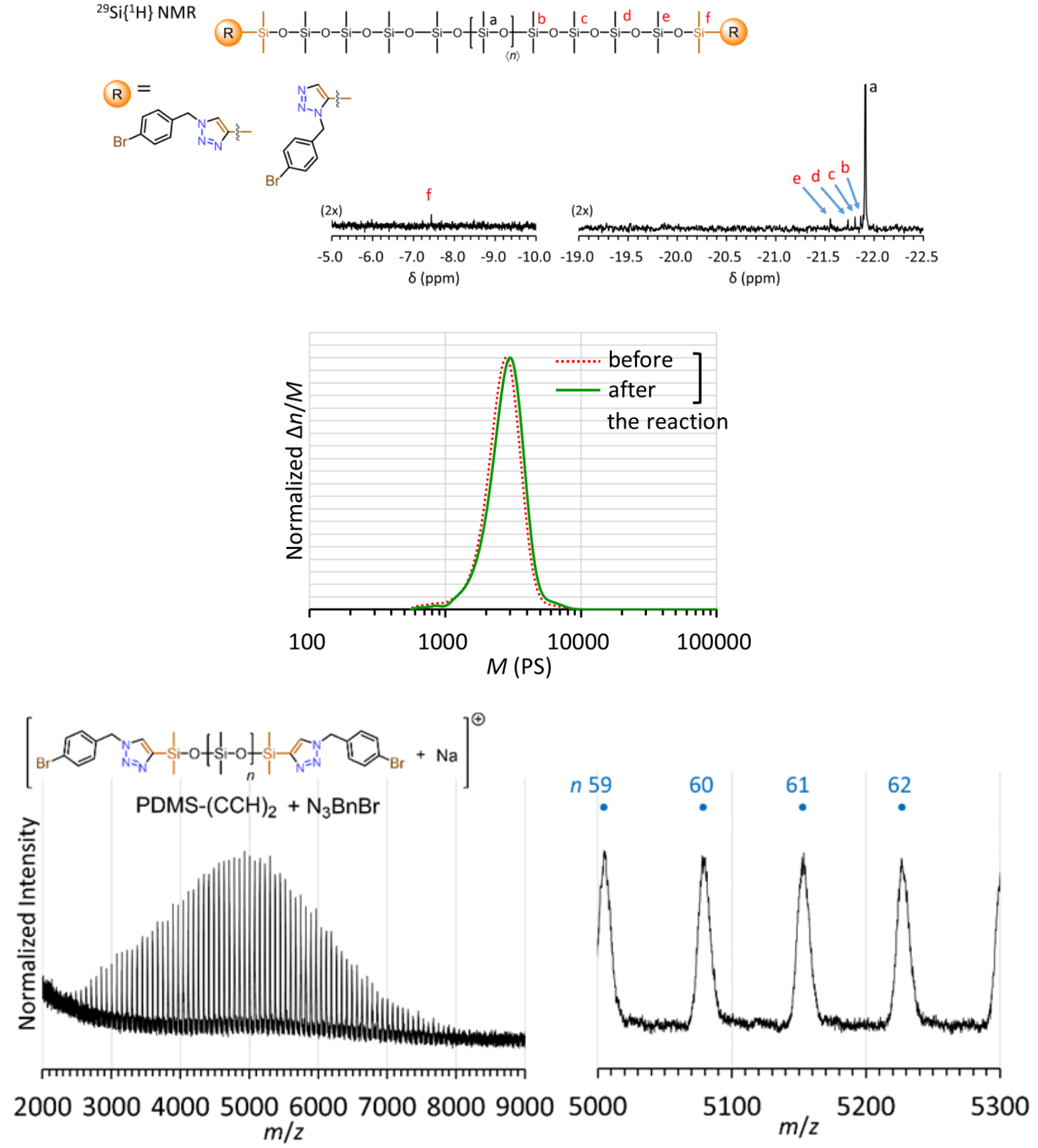

Figure S8. ${ }^{1} \mathrm{H}$ NMR and ${ }^{29} \mathrm{Si}\left\{{ }^{1} \mathrm{H}\right\}$ NMR spectra, molar-mass distribution, and positive-ion MALDI-TOF MS spectra of the product $\left(M_{\mathrm{n}, \mathrm{SEC}}=2.91 \mathrm{kDa}, \bigoplus_{\mathrm{M}}=1.10_{1}\right)$ of the reaction between PDMS- $(\mathrm{CCH})_{2}\left(M_{\mathrm{n}, \mathrm{SEC}}=2.51 \mathrm{kDa}\right.$, $\bigoplus_{\mathrm{M}}=1.09_{9}$ ) and $\mathrm{N}_{3} \mathrm{BnBr}$ under the non-catalytic condition (Table 2, entry 2). 

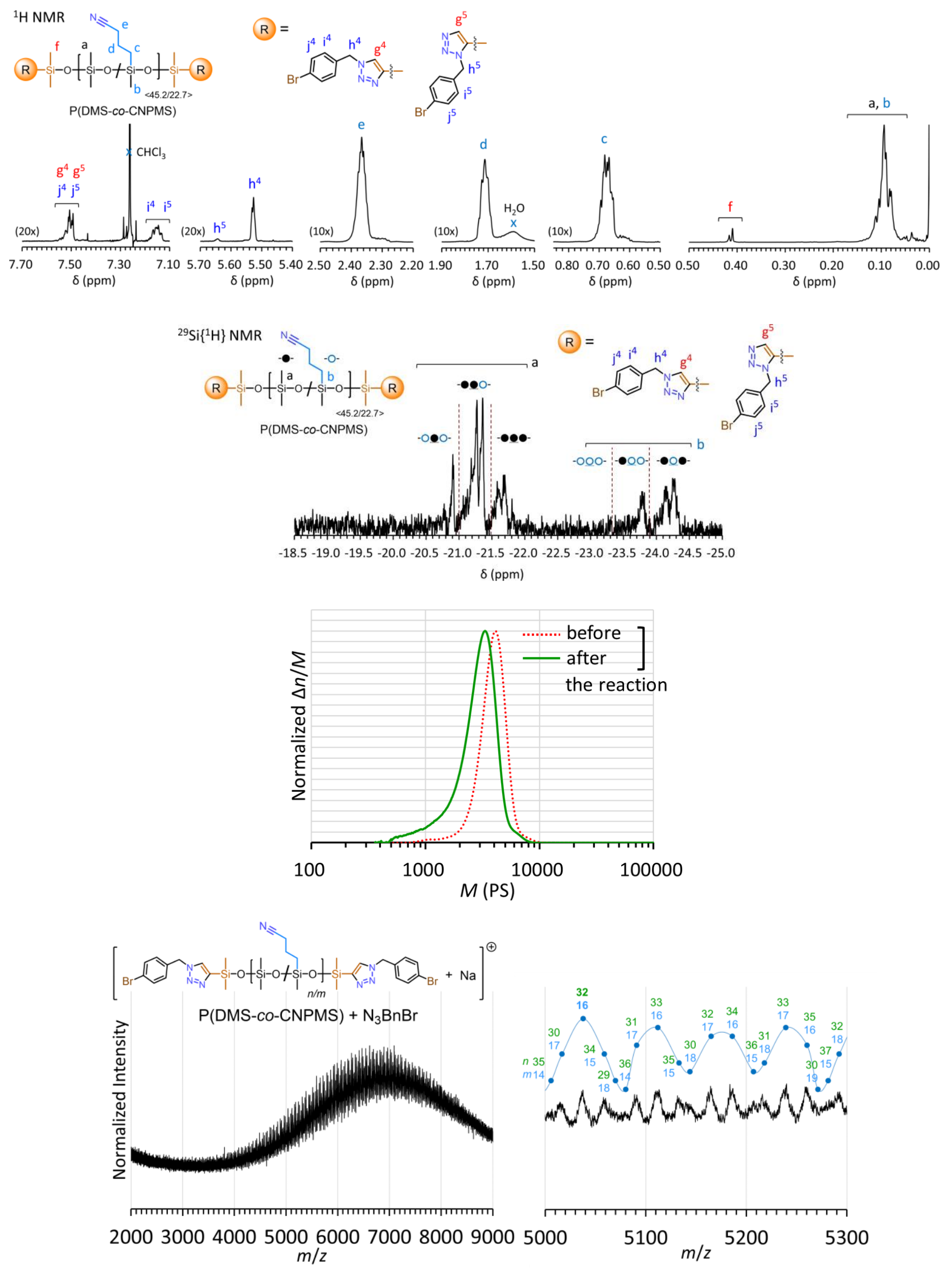

Figure S9. ${ }^{1} \mathrm{H}$ NMR and ${ }^{29} \mathrm{Si}\left\{{ }^{1} \mathrm{H}\right\}$ NMR spectra, molar-mass distribution, and positive-ion MALDI-TOF MS spectra of the product $\left(M_{\mathrm{n}, \mathrm{SEC}}=3.28 \mathrm{kDa}, \bigoplus_{\mathrm{M}}=1.13_{8}\right)$ of the reaction between P(DMS-co-CNPMS $)-(\mathrm{CCH})_{2}$ $\left(M_{\mathrm{n}, \mathrm{SEC}}=3.98 \mathrm{kDa}, M_{\mathrm{n}, \mathrm{NMR}}=6.42 \mathrm{kDa},\left\langle X_{\mathrm{n}, \mathrm{D}} / \mathrm{X}_{\mathrm{n}, \mathrm{CNP}}\right\rangle=45.2 / 22.7\right.$, and $\left.\emptyset_{\mathrm{M}}=1.069\right)$ and $\mathrm{N}_{3} \mathrm{BnBr}$ under the non-catalytic condition (Table 2, entry 5 ). 

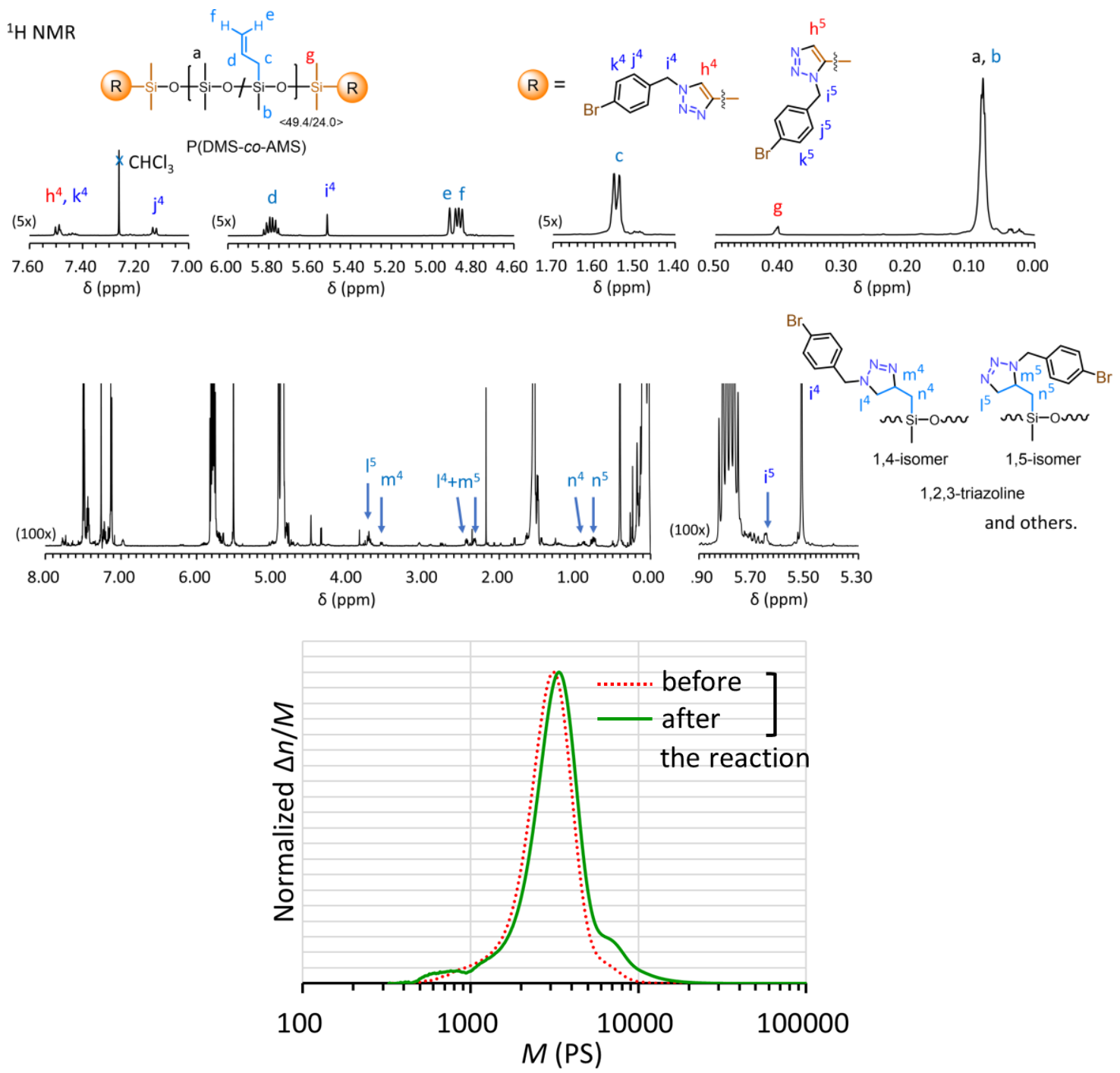

Figure S10. ${ }^{1} \mathrm{H}$ NMR spectrum and molar-mass distribution of the product $\left(M_{\mathrm{n}, \mathrm{SEC}}=3.66 \mathrm{kDa}, \bigoplus_{\mathrm{M}}=1.28_{6}\right)$ of the reaction between $\mathrm{P}(\mathrm{DMS}-\mathrm{co}-\mathrm{AMS})-(\mathrm{CCH})_{2}\left(M_{\mathrm{n}, \mathrm{SEC}}=3.07 \mathrm{kDa}, M_{\mathrm{n}, \mathrm{NMR}}=6.25 \mathrm{kDa},\left\langle X_{\mathrm{n}, \mathrm{D}} / \mathrm{X}_{\mathrm{n}, \mathrm{A}}\right\rangle=49.4 / 24.0\right.$, and $\bigoplus_{\mathrm{M}}=1.14_{8}$ ) and $\mathrm{N}_{3} \mathrm{BnBr}$ under the non-catalytic condition (Table 2, entry 6). 


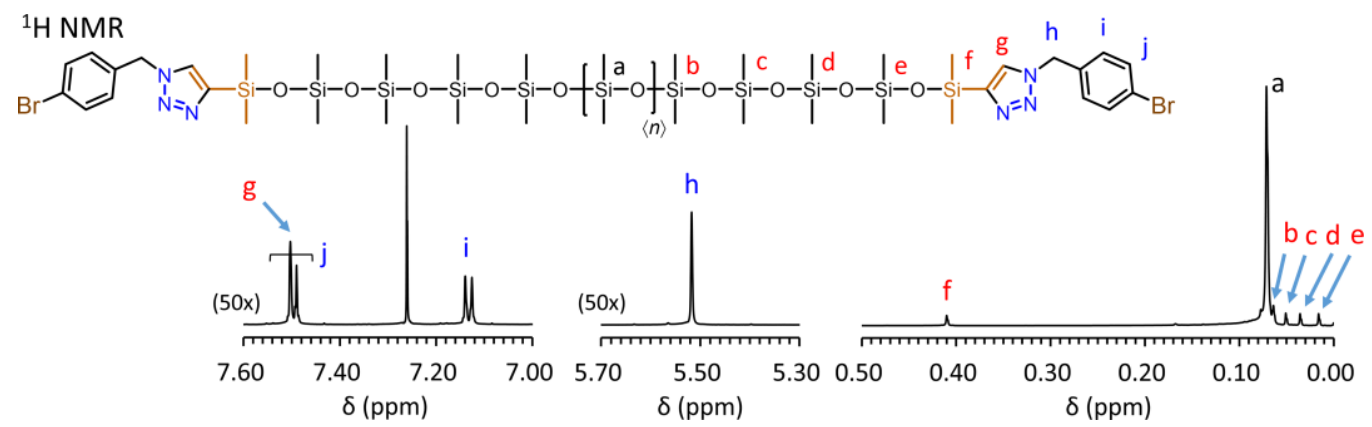

${ }^{29} \mathrm{Si}\left\{{ }^{1} \mathrm{H}\right\} \mathrm{NMR}$
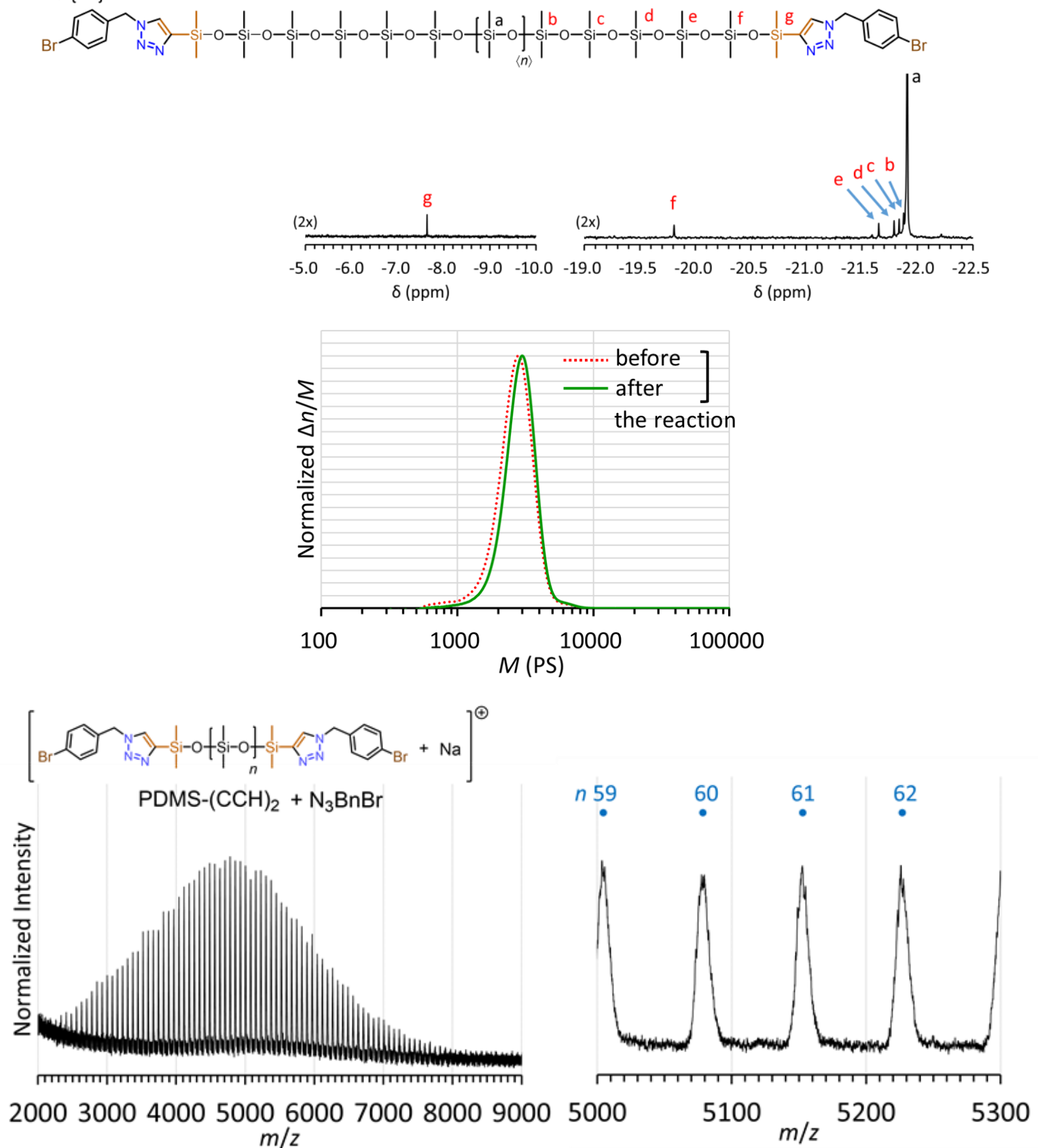

Figure S11. ${ }^{1} \mathrm{H}$ NMR and ${ }^{29} \mathrm{Si}\left\{{ }^{1} \mathrm{H}\right\}$ NMR spectra, molar-mass distribution, and positive-ion MALDI-TOF MS spectra of the product $\left(M_{\mathrm{n}, \mathrm{SEC}}=2.93 \mathrm{kDa}, \bigoplus_{\mathrm{M}}=1.08_{1}\right)$ of the reaction between PDMS- $(\mathrm{CCH})_{2}\left(M_{\mathrm{n}, \mathrm{SEC}}=2.51 \mathrm{kDa}\right.$, $\left.\bigoplus_{\mathrm{M}}=1.109_{9}\right)$ and $\mathrm{N}_{3} \mathrm{BnBr}$ catalyzed by the catalyst $\mathrm{A}\left(\mathrm{CuBr}+\mathrm{Et}_{3} \mathrm{~N}\right.$, Table 2, entry 7). 


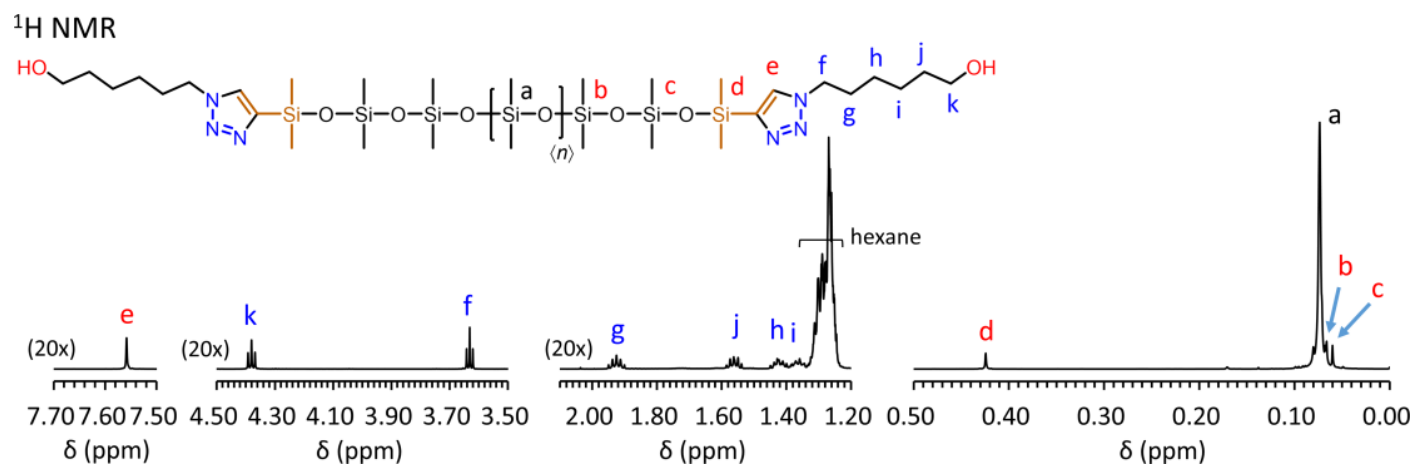

${ }^{29} \mathrm{Si}\left\{{ }^{1} \mathrm{H}\right\} \mathrm{NMR}$
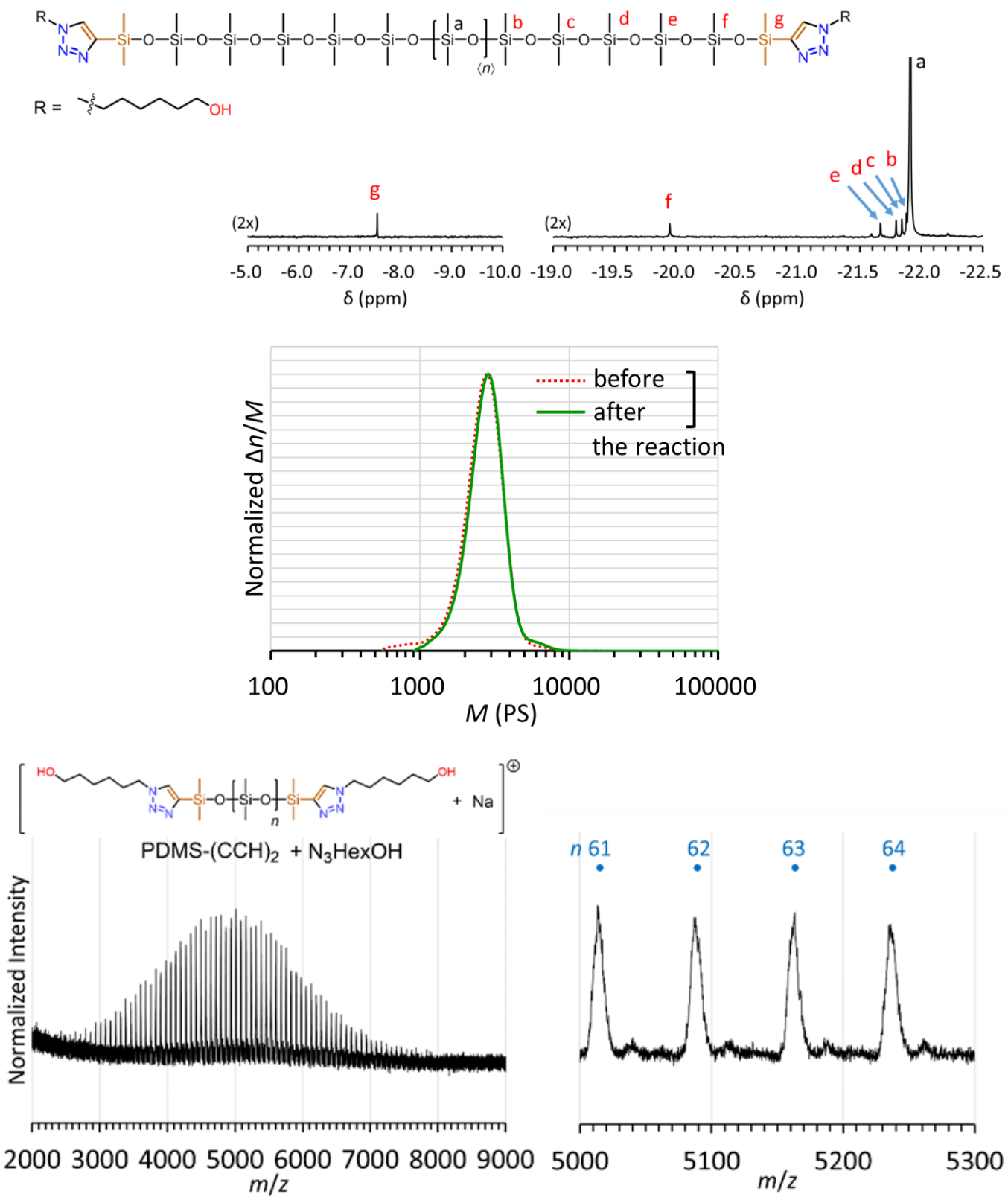

Figure S12. ${ }^{1} \mathrm{H}$ NMR and ${ }^{29} \mathrm{Si}\left\{{ }^{1} \mathrm{H}\right\}$ NMR spectra, molar-mass distribution, and positive-ion MALDI-TOF MS spectra of the product $\left(M_{\mathrm{n}, \mathrm{SEC}}=2.78 \mathrm{kDa}, \bigoplus_{\mathrm{M}}=1.10_{9}\right)$ of the reaction between PDMS- $(\mathrm{CCH})_{2}\left(M_{\mathrm{n}, \mathrm{SEC}}=2.51 \mathrm{~kg}\right.$ $\left.\mathrm{mol}^{-1}, D_{\mathrm{M}}=1.09_{9}\right)$ and $\mathrm{N}_{3} \mathrm{HexOH}$ catalyzed by the catalyst $\mathrm{A}\left(\mathrm{CuBr}+\mathrm{Et}_{3} \mathrm{~N}\right.$, Table 2, entry 9$)$. For the SEC, the hydroxy groups in the product were treated with chlorodimethyl(vinyl)silane and pyridine to obtain the elution curve comparable with the starting PDMS- $(\mathrm{CCH})_{2}$. 

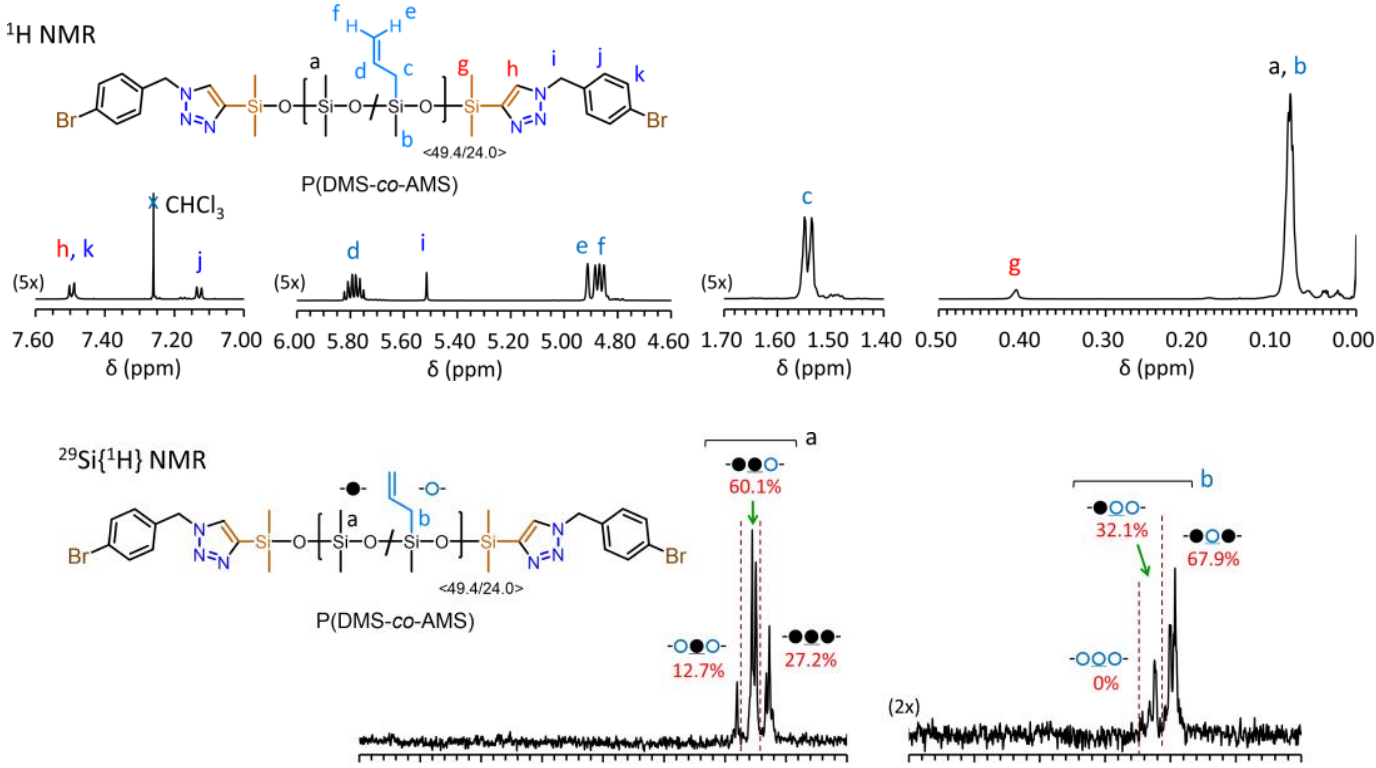

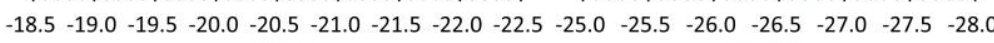
$\delta(\mathrm{ppm})$

$\delta(\mathrm{ppm})$
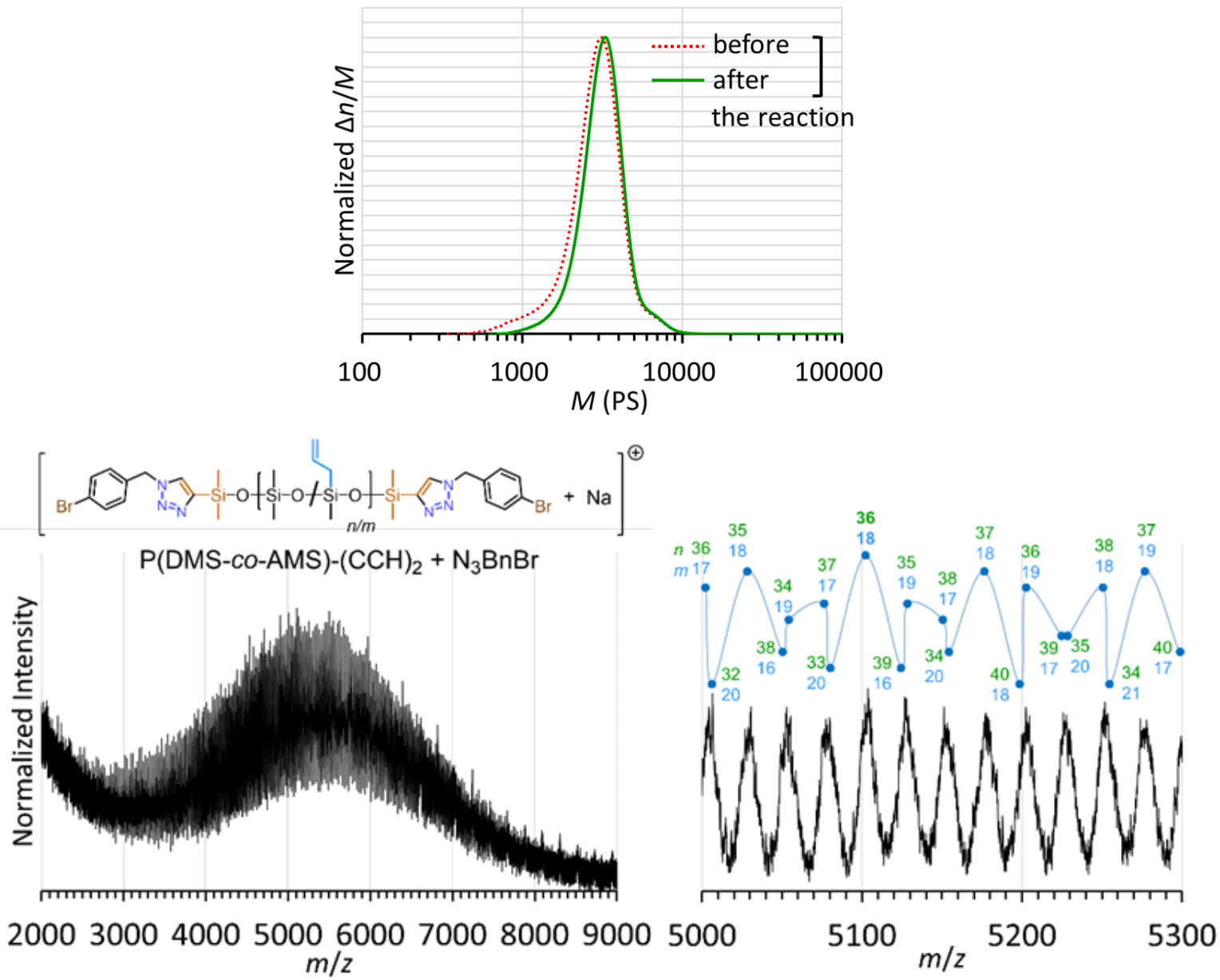

Figure S13. ${ }^{1} \mathrm{H}$ NMR and ${ }^{29} \mathrm{Si}\left\{{ }^{1} \mathrm{H}\right\}$ NMR spectra, molar-mass distribution, and positive-ion MALDI-TOF MS spectra of the product $\left(M_{\mathrm{n}, \mathrm{SEC}}=3.31 \mathrm{kDa}, \bigoplus_{\mathrm{M}}=1.12_{7}\right)$ of the reaction between $\mathrm{P}(\mathrm{DMS}-\mathrm{co}-\mathrm{AMS})-(\mathrm{CCH})_{2}\left(M_{\mathrm{n}, \mathrm{SEC}}\right.$ $\left.=3.07 \mathrm{kDa}, \bigoplus_{\mathrm{M}}=1.14_{8}\right)$ and $\mathrm{N}_{3} \mathrm{BnBr}$ catalyzed by the catalyst $\mathrm{A}\left(\mathrm{CuBr}+\mathrm{Et}_{3} \mathrm{~N}\right.$, Table 2 , entry 11$)$. 


\section{References}

(S1) Fuchise, K.; Sato, K.; Igarashi, M. Precise Synthesis of Side-Chain-Functionalized Linear Polysiloxanes by Organocatalytic Ring-Opening Polymerization of Monofunctional Cyclotrisiloxanes. Macromolecules 2021, 54, DOI: $10.1021 /$ acs.macromol.0c02653.

(S2) Fuchise, K.; Sato, K.; Igarashi, M. Precise synthesis of linear polysiloxanes with a polar side-chain structure by organocatalytic controlled/living ring-opening polymerization of (3-cyanopropyl)pentamethylcyclotrisiloxane. Polym. Chem. 2021, 12, DOI: 10.1039/D1PY00391G.

(S3) Cella, J. A.; Carpenter, J. C. Procedures for the preparation of silanols. J. Organomet. Chem. 1994, 480, 2326.

(S4) Fuchise, K.; Igarashi, M.; Sato, K.; Shimada, S. Organocatalytic controlled/living ring-opening polymerization of cyclotrisiloxanes initiated by water with strong organic base catalysts. Chem. Sci. 2018, 9 , 2879-2891.

(S5) Mizar, P.; Wirth, T. Flexible Stereoselective Functionalizations of Ketones through Umpolung with Hypervalent Iodine Reagents. Angew. Chem. Int. Ed. 2014, 53, 5993-5997.

(S6) Jana, S.; Adhikari, S.; Cox, M. R.; Roy, S. Regioselective synthesis of 4-fluoro-1,5-disubstituted-1,2,3-triazoles from synthetic surrogates of $\alpha$-fluoroalkynes. Chem. Commun. 2020, $56,1871-1874$.

(S7) Li, H.; Fahrenbach, A. C.; Coskun, A.; Zhu, Z.; Barin, G.; Zhao, Y.-L.; Botros, Y. Y.; Sauvage, J.-P.; Stoddart, J. F. A Light-Stimulated Molecular Switch Driven by Radical-Radical Interactions in Water. Angew. Chem. Int. Ed. 2011, 50, 6782-6788.

(S8) Xi, Z.; Rong, J.; Chattopadhyaya, H. Diastereospecific Synthesis of 2'- or 3'-C-Branched Nucleosides through Intramolecular Free-radical Capture by Silicon-tethered Acetylene. Tetrahedron 1994, 50, 5255-5272.

(S9) Kinoshita, H.; Takahashi, T.; Miura, K. Regioselective Synthesis of Multisubstituted Benzenes by Palladium-Catalyzed Intermolecular Reaction of $\beta$-Iodo- $\beta$-silylstyrenes with Alkynes. Org. Lett. 2013, 15 , 2962-2965.

(S10) Horino, Y.; Ishibashi, M.; Nakasai, K.; Korenaga, T. Palladium-catalyzed reaction of $\gamma$-silylated allyl acetates proceeding through 1,2-shift of a substituent on silicon. Tetrahedron 2020, 76, 131493.

(S11) Chao, C.-C; Leibham, A. M.; Bergbreiter, D. E. Hydrocarbon Soluble Recyclable Silylation Reagents and Purification Auxiliaries. Org. Lett. 2016, 18, 1214-1216.

(S12) Fuchise, K.; Kobayashi, T.; Sato, K.; Igarashi, M. Organocatalytic ring-opening polymerization of cyclotrisiloxanes using silanols as initiators for the precise synthesis of asymmetric linear polysiloxanes. Polym. Chem. 2020, 11, 7625-7636. 